SAlaverT A. (2017) - Agricultural Dispersals in Mediterranean and Temperate Europe, Oxford Research Encyclopedia of Environmental

Science. http://environmentalscience.oxfordre.com/view/10.1093/acrefore/9780199389414.0 01.0001/acrefore-9780199389414-e-307.

\title{
$\underline{\text { Agricultural dispersals in Mediterranean and temperate Europe }}$
}

\section{Aurélie Salavert}

\section{Introduction}

Agriculture is the relationship between an exploiting species and one or more exploited species living in an artificial cultivated ecosystem (Mazoyer et al., 1997). In this sense, humans are not the only ones practising agriculture. For exemple, Atta and Acromyrmex, two ant genera from America, cultivate fungi that will constitute the essence of their alimentation. However, man has invented many techniques and artefacts to cultivate a great number of crops. There is currently a wide variety of agricultures in the world, and even now, in the $21^{\text {st }}$ century, agriculture is at the base of most human economies. But what about the first agrarian systems? When did man become a farmer? How did cultivated plants and farming techniques come to Temperate and Mediterranean Europe? Research on the earliest farming systems are highly significant, especially in a globalized context in which new modes of production have been emerging since the 1980s to handle and patent the gene pool of cultivated plants. In Europe, the privatization of agricultural heritage, as well as experimentation to diffuse agriculture beyond Earth, is coming face to face with a renewal of old varieties and food production on a local scale. It shows that agricultural innovations are complex and not linear, even today (Bonneuil et al., 2006).

In the absence of iconographic and written sources for the ancient period, archaeological materials are the most direct evidence for the early agricultures that appeared in several places across the world from around 11,500 years to 5,000 years ago. Agriculture is one of the main components of Neolithic economy, associated with animal husbandry, pottery making, and sedentary habitats in Western Europe (Price et al., 2011). Often qualified as a "revolution" (Childe, 1925), the Neolithic appears today rather more like a transitional phenomenon in the Near East as well as in the diffusion of its economy to Europe. Agriculture did not arrive suddenly. It took around 3,000 years for domesticates to spread from the Aegean to Great Britain and Ireland. But even if it was not a revolution, the invention of agriculture and its dispersal constitutes a crucial change in human economy as well as its relationship with the natural environment. Before becoming farmers and herders, human beings were, for a long time, predators, living lives of hunting and gathering.

This geographical framework includes a territory stretching roughly from the Black Sea in the east to the Atlantic Ocean in the west. In Europe, the Neolithic period is part of the Holocene epoch, which began about 12,000 years ago. The Holocene is characterized by a global warming following the frosty and arid climate of the Pleistocene. The epoch is divided into several chronological zones, defined in particular by palynology, ie, the study of pollen grains conserved in sediment. The beginning of the Neolithic corresponds to the middle of the Atlantic chronozone, characterized by the extension of deciduous oak, to the detriment of the boreal forest composed of birch, pine, and hazelnut in temperate Europe, as well as scot pine and juniper in the Mediterranean. The Mesolithic/Neolithic transition corresponds to the passage from a hunter/gatherer to a agro-pastoral way of life. The period of transition varies, between 
7,000 and 4,000 BC, according to the regions of Europe and their location on the long route of diffusion of agriculture. The primary Neolithic settlement regions in Europe are, roughly, the Balkans, central Europe, and the central and northwestern sides of the Mediterranean basin. This article aims to present the emergence of agriculture in Europe in the middle of the $7^{\text {th }}$ millenium BC, demonstrating the main routes of cultivated plant diffusion to Temperate and Mediterranean Europe, as well as highlighting assumptions about early Neolithic farming systems (Fig. 1).

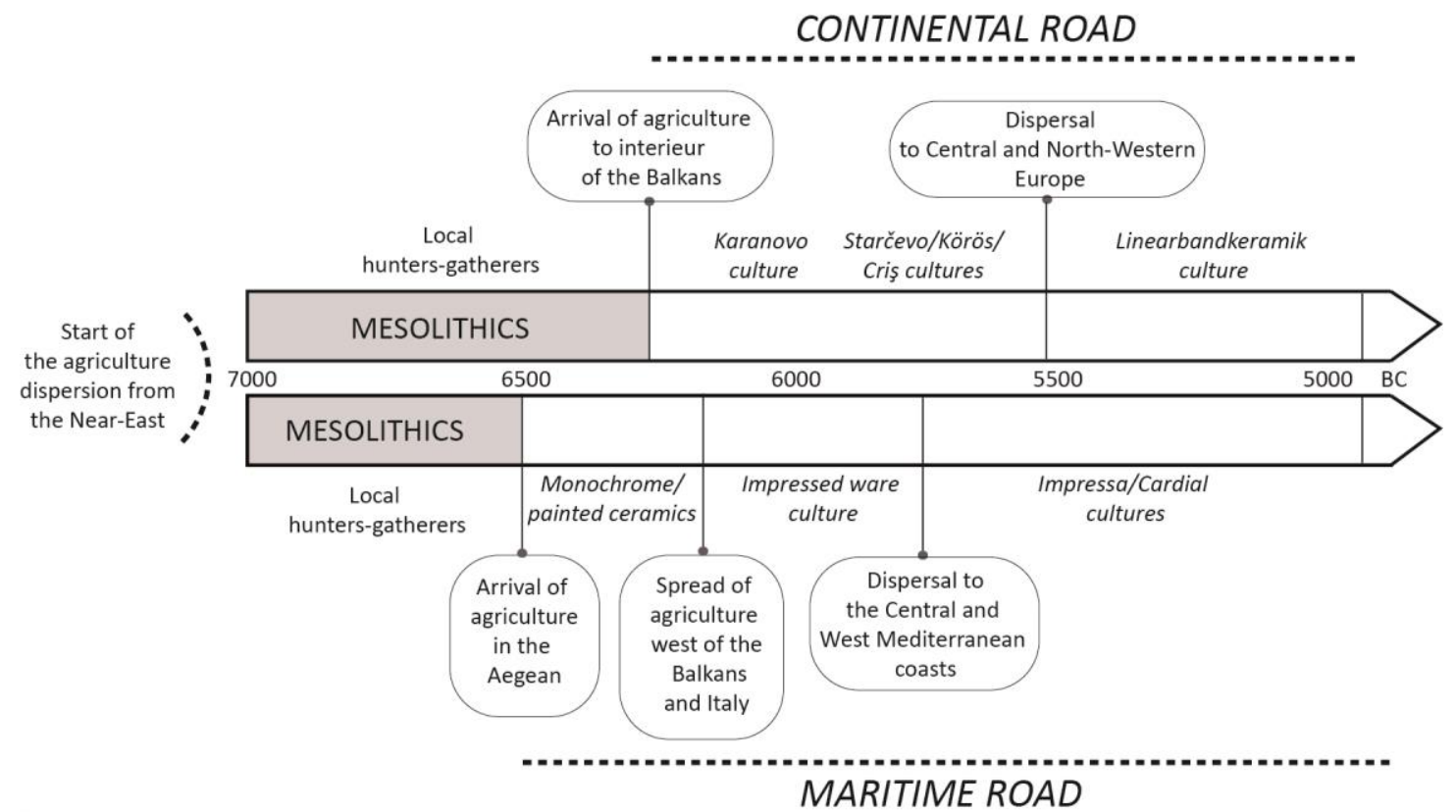

Figure 1: chronological setting of the agriculture dispersal in Western Europe. In italic, main archaeological cultures, defined mainly on ceramic decoration, are mentioned.

\section{Studying the origin of the first agrarian system and its introduction into Europe}

\section{How to study the spread of early agriculture?}

\section{Proxies used to study early agriculture}

Interdisciplinarity is fundamental to the study of past societies, including early crop diversity and the diffusion of agriculture. Farming systems result from the combination of natural, sociocultural, economic, and technical elements (Jouve, 1988). Several types of residues, plant microfossils (phytoliths, pollen grains and starch, organic residues), plant macrofossils (charcoal), artifacts (grinding stones or harvesting tools), and archaeozoology (bone pathology) allow for the study of most of the components, especially the ecosystem context and technological practices. Synthesizing the results and integrating all of the archaeological disciplines and scientific tools used is therefore an arduous task. Even then, this synthesis cannot be exhaustive, due to the mass of data produced by archeology (many proxies are used to study the agricultural system), the large territory in question ( Europe), and the interest aroused by this huge socioeconomic transition in the scientific community (abundant bibliography). On one hand, we will concentrate on the very first moments of the Neolithic primary colonization in the Balkans, Mediterranean, and Temperate Europe. On the other hand, we will rely mainly on the most direct evidence of past agriculture practices, that is to say, the archaeological plant macroremains. 


\section{Definition and methodology of archeobotany}

Archaeobotany is the study of seeds, fruits, and inflorescence parts from archaeological sites. Plant macroremains are collected during excavations and mostly come from sedimentary samples. Water sieving allows for the extraction of fragile plant remains from their sedimentary matrix. Most often, seeds and fruits are charred in Temperate and Mediterranean Europe. This can result from one or a few specific actions in time and space - as in a burnt storage structurebut also disparate events, as in the progressive accumulation of remains resulting from cooking accidents (Bouby, 2000). Others macoremains, such as cereal processing by-products or weeds, are not related to human food but are direct witnesses of past farming practices. Furthermore, the study of wild fruits and seeds allows us to consider the importance of gathering practices in the Neolithic productive economy, even when it is assumed that domesticated taxa consitute the main vegetal input in human diets.

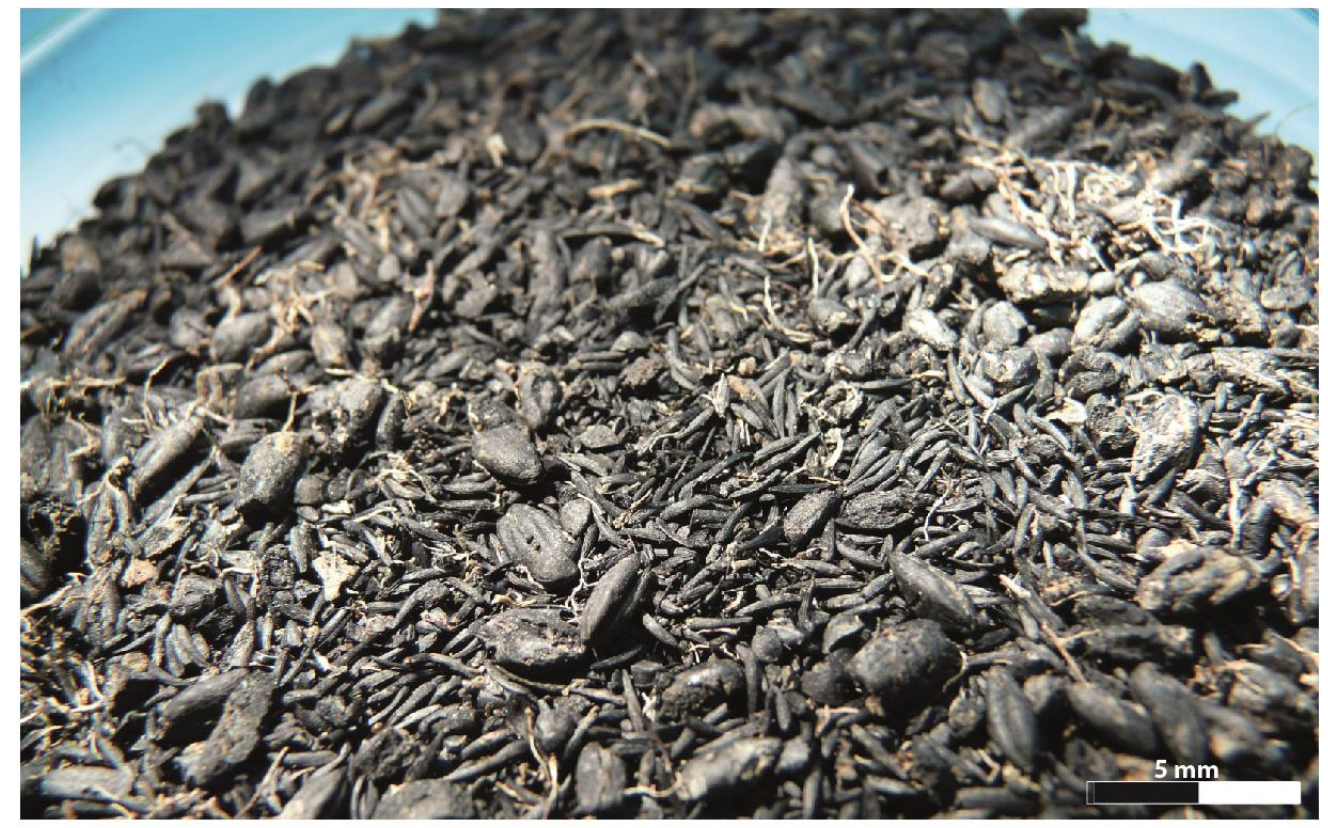

Figure 2: archaeological sample following water sieving, with a mix of emmer, einkorn and a important amount of Lapsana communis, a frequent Neolithic weed in Temperate Europe (Remicourt-en-Bia Flo II, around 5000 $\mathrm{BC}$, Belgium).

After careful separation from other macroremains (micro fauna, shells, lithics, mineral residues), seeds, fruits, and parts of the inflorescence are identified using a binocular microscope, with magnifications from about 10 to 50 times (Fig. 2). The archaeobotanical process is always begun with the morphological observation of plant remains to identify the taxa. For this purpose, the archaeological specimens, often charred and damaged, are compared with specimens from modern seed comparison collections, as well as morphological botanical descriptions. The cultivated plants, and evidences of their mode of production and processing, which reach us, are fragmentary and most often of accidental origin (as is true for many archaeological remains). Indeed, certain types of remains, such as leaves, roots, and tubers, are not clearly identified because of their uncharacteristic anatomy and low resistance to carbonization. In addition, different sampling protocols, unequal analytical corpus, and nonuniform macro-level counting methods across the discipline make it difficult to integrate data from different researchers (Fig. 3). Thus, limiting filters are to be taken into account when the 
archaeobotanist seeks to interpret archeobotanical assemblages and make a comparative work between two regions, for example.

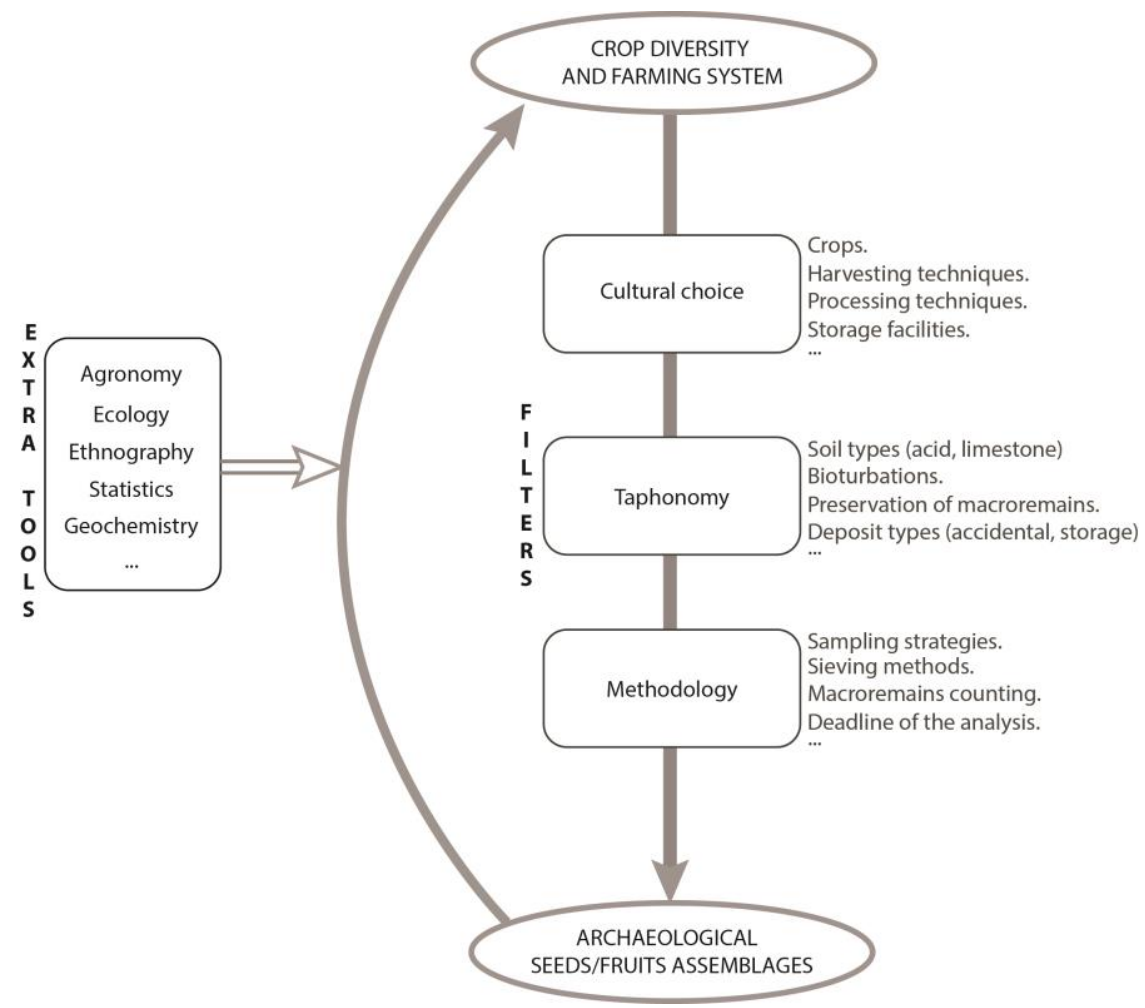

Figure 3: presentation of main filters that come into archaeobotanical studies as well as tools used by the archaeobotanist to recontruct past farming systems.

The first archaeobotanical studies were conducted in Egypt on desiccated seeds from pharaonic tombs, which were studied by C. Kunth (1826). Forty years later, results from the Swiss palafittic sites and the Hallstatt salt mines in Austria were published (Heer, 1865; Unger et al., 1851). In 1968, the creation of the International Work Group for Palaeoethnobotany (IWGP) allowed for a united discipline, organizing an international symposium every three years in Europe, in which the study of the first farming system in the world holds an important place. The domestication of plant species and their introduction into new regions is, indeed, one of the favorite subjects of archaeobotanists. From the 1980s, an increase in archaeological research has enabled the acquisition of archaeobotanical material. The reference work regarding crop domestication, reprinted several times, discusses the origin of cultivated plants and their distribution in the western and central regions of the Asiatic continent (Zohary et al., 2012). In addition, archeobotanical syntheses and comparative works at the regional and supra-regional scale in Europe have appeared in several collective works and articles (e.g. Boogard et al., 2007; Chevalier et al., 2014; Colledge et al., 2007a; Coward et al., 2008).

\section{Contribution of cultivated plants to understanding early crop diversity}

Cultivated plants (cereals, pulses, oleaginous/textile) are represented by their seeds as well as, for cereals, their envelopes (lemma, palea) and the rachis that produce the chaff. The chaff corresponds to byproducts from the processing of cereals and allows for the study of postharvesting stages, such as the way cereals were stored (cleaned seeds, spikelet, ear). Rachis also provide one of the best morphological traits visible through archaeobotany for discriminating wild and cultivated cereals. In a cultivated cereal, the rachis has robust scars, indicating that the 
ears are indehiscent-i.e., they cannot disperse by themselves, unlike wild cereals. For the same reason, and because of the cereal processing, the rachis base is often broken. Seeds or chaff imprints, used in building materials or tempered ceramic, can also provide information about the crops and the use of grain products. Seeds and chaff provide information on crop morphological diversity in the earliest stages of Neolithic dispersal.

For cultivated plants, the rank of the species, in the morphological sense of the term, is most often identifiable. Sometimes only the genus (e.g., Triticum / Hordeum) can be identified due to poor preservation of remains. Sometimes, species cannot be discriminated because of similar morphological criteria (e.g., Triticum aestivum/durum), preventing the appreciation of the whole diversity of past cultivated plants.

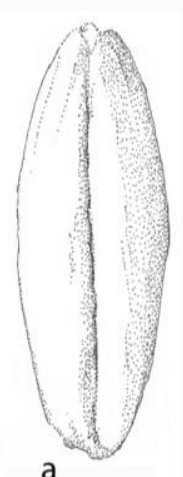

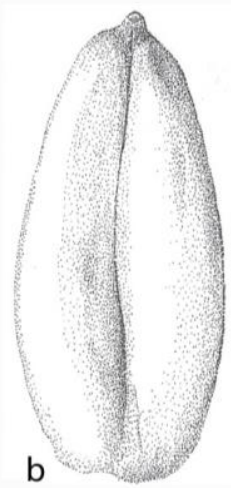
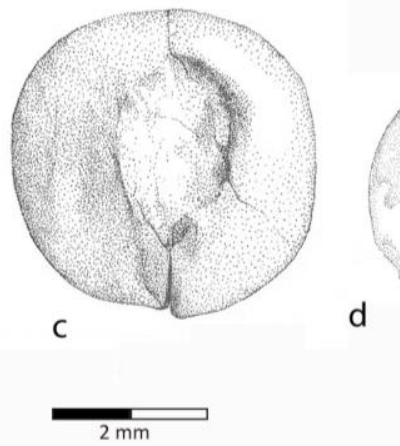

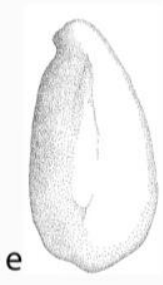

e

Figure 4: seeds of Neolithic cultivated plants from Early Neolithic sites in Belgium. a: Triticum monococcum (einkorn), b: Triticum dicoccum (emmer), c: Pisum sativum (pea), d: Lens culinaris (lens), e: Linum usitatissimum (flax).

In addition to the strictly morphological study, genetic research applied to charred plant macrofossils has been in development since the 2000s (Brown et al., 2015; Schlumbaum et al., 2008). This will provide substantial information on the origin of ancient plant remains, the process of domestication, and the genetic diversity within a field, which is not visible through the seeds or cereal rachis morphology.

\section{Contribution of weeds to study the early farming system}

Weed seeds are also conserved, even in charred conditions. Weeds, from the archaeobotanical point of view, correspond to uncultivated plants installed in the fields. They result from the cleaning of cereals or pulses and are direct indicators of the exploited agricultural environments and the agricultural techniques used. In a cultivated plot, the flora is the result of a combination of agro-cultural factors (depth of plowing, seedlings' seasonality) and the environment (precipitation, temperature, soil properties) that interact in complex ways. Arcaheological weed assemblages are therefore the product of past farming systems.

The identification of weeds within the rank of species is more problematic then for cultivated plants, as it depends on the preservation of the seed, the experience of the archaeobotanist, and the richness of the reference collections of current plants. Indeed, the diversity of wild plants is much wider than cultivated plants. Moreover, botanical identification depends on several anatomical criteria (size, color of flowers, number of petals, arrangement of leaves, etc.). However, most often, only the seed is conserved in an archaeological context. 
Interpretation of weed assemblages is based on the current flora ecology and on farming experiments (Bogaard, 2002; Jones, 2005; Jones et al., 1995). When the weed identifications are precise enough (to the specie level), the phyto-sociology of these plants are indicators of the mode of cultivation. Archaeological weeds can be classified according to their current cooccurrences in fields, in large classes such as Secalinetea, corresponding to winter crops, and Chenopodietea, corresponding to summer crops. However, both classes may cohabit in the same plot, and the weed flora would be influenced by how the land is worked rather than the sowing season (Behre et al., 1991; Lundström-Baudais, 1986). For example, Chenopodium album, which is regularly identified in Neolithic archaeobotanical assemblages, is found in both summer and winter crops (Bogaard et al., 2001). It is then much less developed and has a smaller size (Lundström-Baudais, 1986). The main limit to reconstructing the Neolithic farming system in general, including the intensity of crops, the seasonality, and the sustainability of the fields, is due to the current difficulty in finding (by ethnology) or reproducing (by experimentation) farming systems in an ecological and socioeconomical setting comparable to those of past societies.

For the last fifteen years, the method called Functional Interpretation of Botanical Survey (FIBS) has been used extensively to interpret weed assemblages. FIBS is based on the autoecology of weed species, including individual attributes such as length of growth period, canopy height, or ability to regenerate after significant soil disturbances (Bogaard et al., 1998; Jones et al., 2000). It makes it possible to go further in interpreting past agricultural regimes (intensive, extensive) and crops' seasonality. The growth conditions of the cultivated plants (water supply, soil fertility) can also be specified thanks to the stable isotopes of carbon $(\delta 13 \mathrm{C})$ and nitrogen $(\delta 15 \mathrm{~N})$ carried out on cereal seeds in particular (Fiorentino et al., 2015). These analyses, which will certainly develop exponentially in the future, constitute a promising tool complementary to the interpretations of archaeological assemblages of weeds to understand how plants were cultivated.

\section{At the origins of agriculture in the Near East}

\section{Geographical location of wild progenitors of Neolithic crops}

There is currently a consensus that crops found in European archaeological sites were not domesticated locally. Most of them come from the Near East. However, the question of domestication attempts of cereals and pulses before the arrival of Neolithic groups is still subject to debate in both Temperate and Mediterranean Europe.

Taxonomic classification as well as cynogenetic and molecular affinities make it possible to identify, with more or less precision, the wild ancestors of cultivated plants. However, not all of them have beenidentified with certainty, in particular for pulses. For example, Triticum turgidum ssp. dicoccoideae is the wild progenitor of emmer ( $T$. dicoccum), one of the first wheats domesticated in the Near East, whereas the wild ancestor of the faba bean (Vicia faba) is still unkown (Zohary et al., 2012). The presence of wild ancestor populations in one region is, thus, the main criteria in favor of the local domestication of this plant in the Neolithic period. By the end of the $19^{\text {th }}$ century, botanists such as de Candolle (1883) and, later, Vavilov (1951) worked on these issues, locating the Fertile Crescent as one of the world's centers of plant domestication. 


\begin{tabular}{|c|c|c|}
\hline GROUP & LATIN NAMES & ENGLISH COMMON NAMES \\
\hline \multirow{9}{*}{$\begin{array}{c}\text { WILD } \\
\text { AND } \\
\text { CULTIVATED } \\
\text { CEREALS }\end{array}$} & Hordeum vulgare subsp. spontaneum (K.Koch) Thell. & Wild barley \\
\hline & Hordeum vulgare subsp. vulgare $\mathrm{L}$. & Cultivated hulled barley \\
\hline & Hordeum vulgare subsp. nudum $\mathrm{L}$. & Cultivated naked barley \\
\hline & Triticum aestivum $\mathrm{L}$. & Bread wheat \\
\hline & Triticum monococcum $\mathrm{L}$. & Einkorn \\
\hline & Triticum monococcum subsp. aegilopoides (Link) Thell. & Wild einkorn \\
\hline & Triticum turgidum L. ssp. dicoccoides (Körn. ex Asch. \& Graebn.) Thell. & Wild emmer \\
\hline & Triticum turgidum L. ssp. dicoccon (Schrank) Thell. & Cultivated emmer \\
\hline & Triticum turgidum subsp. durum (Desf.) Husn. & Macaroni wheat \\
\hline \multirow{8}{*}{$\begin{array}{c}\text { WILD } \\
\text { AND } \\
\text { CULTIVATED } \\
\text { PULSES }\end{array}$} & Cicer arietinum $\mathrm{L}$. & Chickpea \\
\hline & Lathyrus cicera $\mathrm{L}$. & Red pea \\
\hline & Lathyrus sativus L. & Grass pea \\
\hline & Lens culinaris Medik. & Lens \\
\hline & Pisum sativum $\mathrm{L}$. & Pea \\
\hline & Vicia ervilia (L.) Willd. & Bitter vetch \\
\hline & Vicia faba $\mathrm{L}$. & Broad bean \\
\hline & Vicia sativa $\mathrm{L}$. & Common vetch \\
\hline \multirow{3}{*}{$\begin{array}{l}\text { OIL/TEXTILE/PSYCHOACTIVE } \\
\text { PLANTS }\end{array}$} & Linum usitatissimum $\mathrm{L}$. & Flax \\
\hline & Papaver somniferum $\mathrm{L}$. & Opium poppy \\
\hline & Papaver somniferum subsp. setigerum (DC.) Arcang. & Wild poppy \\
\hline \multirow{8}{*}{ WEEDS } & Chenopodium album $\mathrm{L}$. & Goosefoot \\
\hline & Bromus secalinus $\mathrm{L}$. & Rye brome \\
\hline & Bromus tectorum $\mathrm{L}$. & Drooping brome \\
\hline & Fallopia convolvulus (L.) Á.Löve & Black-bindweed \\
\hline & Galium aparine $\mathrm{L}$. & Cleaver \\
\hline & Lapsana communis Juss. & Nipplewort \\
\hline & Setaria viridis (L.) P. Beauv. & Wild/green foxtail millet \\
\hline & Setaria verticillata (L.) P. Beauv. & Bristly foxtail \\
\hline
\end{tabular}

Table 1: main crops and weeds mentioned in the text. 


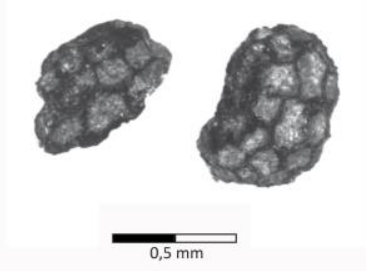

Most putative wild progenitors are, thus, currently absent in Western Europe, except for the Balkans. Triticum aegilopoides, the ancestor of einkorn (T. monococcum); Lens orientalis, the ancestor of lens (L. culinaris); and Hordeum spontaneum, the ancestor of barley (H. vulgare) are present in Southeast Europe today (Redden et al., 2015; Valamoti et al., 2007; Zohary et al., 2012). Thus, the hunter-gatherers of the Balkan Peninsula had at their disposal populations of the wild progenitors of cultivated cereals and pulses. At Franchthi Cave, in the Peloponnese (southern Greece), populations of barley, lentils, and wild oats have been found to be exploited during the Mesolithic, in archaeological layers dating to around 7900-7500 BC (Valamoti et al., 2007). On the following Neolithic archaeological levels, cereals and pulses were identified on the morphological base, which could suggest a domestication process on that site. However, the absence of transitional domestication traits supports the hypothesis of the sudden introduction of cultivars in their fully domesticated morphology during the Initial Neolithic, in the first half of the $7^{\text {th }}$ millenium BC (Perlès, 2001).

Wild pulses and cereals are identified in other Mesolithic layers in Mediterranean Europe. For example, in the L'Abeurador, a cave located in the Massif Central (southern France), numerous charred pulses and seeds of the genera Vicia, Lathyrus, and Pisum have been identified in 
Mesolithic levels dating to around 9000 BC (Vaquer et al., 2009). These three genera are part of the founder crop package of the Near East. Their identification rank remains imprecise due to poor conservation of macroremains. We do not know whether these Mesolithic wild pulses correspond to wild progenitors. At L'Abeurador, wild pulses have been found together with hazelnut shells, dogwood seeds, and wild grape seeds, which were probably consumed by inhabitants of the cave. Thus, as in Franchthi cave, wild pulses could also have been intensively picked up by Mesolithic hunter-gatherers before the introduction of cultivated plants in the Mediterranean region by Neolithic farmers.

These examples demonstrate that exploitation of wild resources, among other wild cereals and pulses, potentially ancestors of Neolithic crops, are common in Mesolithic sites, mainly in the Mediterranean region. However, intensive wild plant gathering does not necessarily involve local domestication processes. Indeed, in Neolithic Europe, the archaeological seeds and elements of cereal chaff are domestic from the morphological point of view. There are no transitory forms, as may be suspected in the Near East (Tanno et al., 2006).

\section{Process of domestication in the Near East}

The domestication of a plant is a long process. First, the wild ancestor is collected, more or less intensively. Man, in a way, cultivates wild populations before they depend entirely on him for reproduction. The focus of domestication at the origin of the cultivated plants identified on the European Neolithic sites, mainly cereals and pulses, is located in the Fertile Crescent, that is to say, the southeast of Anatolia, the Middle Euphrates, and the Southern Levant.

The process of domestication began in the Epipalaeolithic, about 12,000 years ago. Some authors have estimated that the climatic deterioration of the recent Dryas (12,500-11,500 BP), which corresponds to the end of the last glacial period and which results in a decrease in temperatures, would have played a stimulating role in the choice of cultivation of cereals, to compensate for climatic risks. According to Willcox (2005), the models explaining the transition to agriculture place too much importance on this event. Indeed, although the deterioration is undeniable, the climatic conditions had only a moderate effect on vegetation. In addition, agriculture, which depends on a stable climate, was established after the Younger Dryas, at the end of the $9^{\text {th }}$ millennium BC. The availability of wild cereals, ancestors of domestic cultivars, is one of the key factors in understanding the beginning of agriculture. This availability depends on soil types, precipitation, and temperatures. In the 1990s, it was thought that there was only one center of domestication, followed by a dispersal of cultivars. Since the early 2000s, the hypothesis of polycentric domestication in the Fertile Crescent has been accepted on the basis of the distribution of wild populations, archaeobotanical data, and genetic analyses of modern cereal populations (Gebel, 2004; Willcox, 2005). The transition from harvesting to fully established agriculture was gradual, taking several hundred years (Willcox, 2007). The domestication occurred independently in two regions: southeastern Anatolia/Middle Euphrates and the Southern Levant. The presence of a water source in these regions is surely the primary necessity that led to the establishment of villages, even if the wild cereals were sometimes distant (Willcox, 2005).

\section{The founder crop package}

At the end of the $8^{\text {th }}$ millenium BC, corresponding to the Pre-pottery Neolithic B period ( $P P N B$, 7500-7000 BC), domestic plants and animals were at the basis of subsistence. The founding crops, also called the "Neolithic crop package," consisted of hulled cereals: einkorn (Triticum 
monococcum), emmer (Triticum dicoccum), and barley (Hordeum vulgare subsp. vulgare) (Zohary, 1996). The free-treshing wheat (Triticum aestivum/durum) and naked barley (Hordeum vulgare subsp. nudum) were domesticated in a second phase (Willcox, 2007). Pulses were reprented by lens (Lens culinaris), pea (Pisum sativum), chickpea (Cicer arietinum), and vetch (Vicia ervilia). Secondary pulses such as broad bean (Vicia faba) and grass pea (Lathyrus sativus) do not seem to have met the same success, depending on location in the Fertile Crescent, and are thus not included systematically in the founding crop package. Flax (Linum usitatissimum) is the only textile and oilseed plant in the package. Thus, the Neolithic populations that spread into Western European have potentially five types of cereals, at least four pulses and one oil and textile plant.

\section{General chronological setting of agriculture dispersal to Europe}

Hypotheses regrading the roads of diffusion and the parameters for the outbreaks of Neolithic migration rely on a large number of proxies, such as radiocarbon dating and the comparison of material productions, genetic, climatic, archaeozoological, and archaeobotanical data.

Radiocarbon dating is the strongest tool pointing to the arrival of an agricultural economy from the Near East. Cereal grains, or associated archaeological contexts, are found earlier in the East than in the West. The diffusion westward, from the Near East via Anatolia, started from around the very beginning of the $7^{\text {th }}$ millenium BC. The pioneer front of colonisation spread quickly from the core zone, as shown by early evidence of cultivated plants in the late Pre-pottery Neolithic A (PPNA, 9500-8700 BC) site Klimonas in Cyprus, involving as well an early knowledge of navigation techniques from at least ten thousand years ago (Vigne et al., 2012). Rapid climate deterioration (aridification) or demographic pressures are often suggested as triggers for the diffusion process to Western Europe (Berger et al., 2009; Bocquet-Appel, 2011; Weninger et al., 2006).

By the mid-1960s, Clark (1965) proposed a model of diffusion from the Near East to Western Europe starting before $5200 \mathrm{BC}$. Since then, thanks to the increasing number of archaeological excavations and radiocarbon datings, which are also more precise, the diffusion of Neolithic economy has become better understood. In the early 1970s, a new theory proposed an advancement at an average speed of about $1 \mathrm{~km} /$ year (Ammerman et al., 1971). However, the linear progress is questioned, because even if it was indeed fast, barriers are recorded in several European regions, as in the Pô plain (north Italy), the Biscay Bay (north of Spain), and the Hungarian plains. Currently, the arrhythmic diffusion, or boom and bust model, is the most popularly argued theory (Guilaine, 2003; Mazurié de Keroualin, 2003; Shennan et al., 2013). It should be noted that it is the movements of the components of the Neolithic economy, notably the seeds of cultivated plants, and not strictly those of the people that are considered (Rasse, 2008).

Two main streams of diffusion to Europe are identified: by maritime route along the north Mediterranean coasts (Impressa/cardial road) and by land along the main water courses of Southeast and Central Europe, such as the Danube and the Rhine (Danubian road) (RowleyConwy 2011). Climate (late frosts in temperate zones) and topography (mountainous areas) are probably not the only factors to have influenced the rhythm and the diffusion trajectories of the first farmers in Europe. Internal factors specific to each of the Neolithic societies certainly greatly influenced their way of managing the sustainability of their socioeconomic systems (Manning et al., 2016; Rasse, 2008). 
The question of the contribution of local Mesolithic groups to the spread of Neolithic economy is also still widely discussed (e.g. Hadjikoumis et al., 2011). Diffusion processes may take slightly different forms (contacts, exchanges, acculturation) depending on cultural contexts and geographical locations. For example, despite arguments in favor of the introduction of fully domesticated plants at Franchthi Cave, the artifacts (stone tools, ornaments) present a strong continuity between Mesolithic and Neolithic horizons, which could correspond to a brief acculturation episode by local hunter-gatherers during the "Initial Neolithic" (Perlès, 1990). This could be a local phenomenon that cannot be applied generally to all sites with a succession of Mesolithic and Neolithic levels in southern Greece (Perlès et al., 2013). This example illustrates quite well the probably complex process of Neolithic economy diffusion from the Near East to Europe, especially in the Balkans, at the origin of the two main streams of Neolithisation to the west and north of the European continent.

\section{Diversity of crops and farming systems in Mediterranean and Temperate Europe in the Neolithic}

\section{Diversity of first cultivated plants in the Balkans}

\section{Chrono-cultural background of the agriculture dispersal in the Balkans}

The east of the Balkan Peninsula (Greece, Macedonia, and Bulgaria) is the first point from which the Neolithic economy spread quickly to Europe. Based on the evidence ceramic and lithic artifacts and architecture, this complex has a clear Near Eastern origin, in the cultural continuity of the final PPNB period (Mazurié de Keroualin, 2003). The Neolithic economy arrived in the Peloponnese and Macedonia about $6500 \mathrm{cal} \mathrm{BC}$, before the first evidence in Thessaly and Bulgaria, suggesting that multiple points of contact could have occurred during the second half of the $7^{\text {th }}$ millennium BC in the Aegean and Balkans (Lespez et al., 2013; Perlès et al., 2013). Thus, migration from Anatolia to the Aegean and Thrace regions may not correspond to a single event but to separate waves of diffusion, both by sea and land (Özdoğan, 2011). The Struma, Maritsa, and Vardar valleys in southwest Bulgaria could be the primary roads of Neolithic diffusion to the interior of the Balkan Peninsula around 6200-6100 BC, with the Karanovo and the Starčevo/Körös/Criş cultures (Lichardus-Itten et al., 2006). The first farming groups settled in fertile open lands of the Great Hungarian plain and would give birth to the widespread Linearbandkeramik $(L B K)$ culture in Central Europe (see "TEMPERATE DISPERSAL"). They were probably not greatly constrained by the environment, especially in the eastern Balkan Peninsula. In addition, the hunter-gatherers' population density was probably very low at their arrival.

The settlement types are varied. There are caves, such as Franchthi, which can be interpreted as a shepherd shelter, seasonal or complementary to a permanent site not discovered yet (Mazurié de Keroualin, 2003). Perennial sites are also encountered. They present square or rectangular house plans of varying sizes, constructed of brick or cob, as in Neo Nikomedeia in Macedonia or Kovačevo in Bulgaria (Lichardus-Itten, 2012). Both types of sites have provided archaeobotanical material. The fine pottery was generally painted. Sheep and goat seem to predominate at the very beginning of farming diffusion (Mazurié de Keroualin, 2003).

The west of the Peninsula is often considered separately in archaeological literature, probably because this region doesn't correspond, from a cultural point of view, to the Balkano-Anatolian complex. Two roads of diffusion to the Adriatic and south of the Carpathians are identified 
(Forenbaher et al., 2005; Orton et al., 2016). The maritime road corresponds to the so-called "Impressed Ware culture" (6100 BC; see "MEDITERRANEAN DISPERSAL").

\section{Crop diversity in the Balkans}

A consequent amount of archaeobotanical studies have been carried out in this pioneer colonization zone, i.e., Bulgaria and Greece (Colledge et al., 2004, 2007b; Marinova, 2007; Marinova et al., 2012, 2014; Valamoti et al., 2007). On the other hand, very few data are available to the east of the Balkan Peninsula, especially for early Neolithic coastal settlements.

In these regions, the crop package is consistent with what is known in the Near East. It is composed of hulled wheat, hulled and naked barley, free-threshing wheat, a range of pulses such as lentil, pea, chickpea, and bitter vetch, and flax. From a quantitative point of view, hulled wheats (emmer and einkorn) seem to be the most important crops in southeast Europe (Marinova et al., 2014). However, the quantitative criterion is not very relevant for comparing, as the hulled/naked wheats ratio depends on the chronology of the archaeological sites, the number of sites and samples studied, taphonomy, and past human practices.

Few qualitative variations can be noted in the group of pulses between Greece and southwest Bulgaria. First, chickpea is present but rare. It seems that this pulse is not present in the north of Greece, although it has been identified in many sites in South Bulgaria, such as Kovačevo. However, in this site, chickpea is associated with the more recent stages (from $5600 \mathrm{BC}$ ) of the Neolithic in Southern Bulgaria, while it is not mentioned in the north (Marinova et al., 2008; Valamoti et al., 2007). This confirms that Neolithic economy might have penetrated Europe at many different points and times. Thus, not all plants came suddenly, suggesting a potential break in the transmission process. Second, grass pea is continuously present in southeast Europe, regarding the founder crop package, and the importance of this pulse in the Balkans is pointed out (Kislev, 1989; Valamoti et al., 2007). Indeed, concentrations of grass pea have regularly been identified in Early Neolithic sites in Bulgaria and Greece (Valamoti et al., 2011). Lathyrus cicera, the putative wild ancestor of L. sativus, is distributed in Turkey as well as Greece and Transcaucasia (Zohary et al., 2012).

\section{Diversity of first cultivated plants in the Mediterranean}

\section{Chrono-cultural background of the agriculture dispersal in the Mediterranean}

A synthesis of radiocarbon dates, many on cereal seeds, from early Neolithic sites of Italy, southern France, and Iberia indicates that the spread of Neolithic economy took place between 5700 and $5500 \mathrm{BC}$, by maritime road (Zilhão, 2014). It therefore took no more than a couple of centuries to spread from the Thyrrenian to the Albora coast. The diffusion of human groups, their economy, and ideas over more than $3000 \mathrm{~km}$ of coastal territories was then quite rapid, but probably not linear and continuous (Mazurié de Keroualin, 2003). Ceramic style as well as radiocarbon dating compilation indicates that different Neolithic groups may have arrived simultaneously around $5700 \mathrm{BC}$ at different points in the northeastern Iberian Peninsula (Morales Hidalgo et al., 2010). Furthermore, a long period of stasis seems perceptible before the first domesticated plants reached north-central Spain (Zilhão, 2014). Indeed, Biscay Bay, in the Cantabrian region, was not reached until the middle of the $5^{\text {th }}$ millennium, as evidenced by wheat grain emmer dating to $4400 \mathrm{BC}$ (Peña-Chocarro et al., 2005). At first, the pioneering advance seems rather concentrated on the coastal areas, before quickly moving inland and even into higher altitudes via major river systems (Guilaine et al., 2007). 
These pioneer communities are part of a large cultural entity, defined mainly on ceramic decoration and technology, called the Impressa/Cardial complex.. In the central and western Mediterranean Basin, the ceramic paste was decorated with impressions and incisions with fingers, nails, varied tools, or shell edges, such as cardium, which gave its name to the Cardial culture (Mazurié de Keroualin, 2003). Impressa ceramics are more characteristic of the early Neolithic in Italy and southeast France, while the Cardial style is encountered in the western part of the Mediterranean Basin.

Village organisation and extent, as well as architectural techniques for housing, are not well known for the Early Neolithic in the Mediterranean. Many settlements are found in the open air with light structures, or in rock shelters, which do not lend themselves to the conservation of archaeological structures or archaeobotanical remains. Rich and fertile soils in the valley floors seems to have been appreciated and utilized by the first farming communities for their settlements, as along the central coast of the Iberian Peninsula (Pérez-Jordà et al., 2013). A few sites have been preserved under waterlogged conditions, allowing for an outstanding preservation of organic material. Many wooden posts were discovered at La Marmotta (Bacciano Lake, central Italy) and at La Draga (Banyoles Lake, northeast Spain). These huts could correspond to long-term open-air settlements, the building of which would need a substantial labour investment (Fugazzola Delpino et al., 2010). These two types of habitats could be interpreted as the co-existence of different mobility patterns (semi-mobile or permanent) and economic strategies (herders or farmers) from the early Neolithic (Mazurié de Keroualin, 2003). The same variabilities are visible in the livestock package, in which the proportions of pigs, sheeps/goats, cows, and wild fauna, as well as sheep morphotypes, are different depending on location and whether the sites are attributed to the Impressa or Cardial cultures (Rowley-Conwy et al., 2013; Vigne, 2007).

\section{Crops diversity in the Mediterranean}

In Italy, despite the substantial amount of sites studied, the number of remains identified is generally low. However, some Early Neolithic sites, as La Marmotta in Central Italy and Sammardenchia in the Pô Plain, have been subject to systematic archaeobotanical studies, which allow for a substantial overview of the crop package in the coastal Central Mediterranean (Rottoli et al., 2007, 2009). In France, the number of data is, to date, very weak (Gassin et al., 2010). In the Iberian Peninsula, several sites have yielded important and well-preserved datasets, as on the lakeshore site of La Draga in Catalonia and Cova de l'Or and Los Castillejos on the southeastern coast of the peninsula (Antolín et al., 2011, 2012; Rovira, 2007). Recent regional syntheses give substantial data on cultivated plants in these regions and the variation of crop package composition at the supra-regional scale (Antolín et al., 2015; Buxó, 2007; PeñaChocarro et al., 2013; Pérez Jordà et al., 2013; Zapata et al., 2004).

From a qualitative point of view, the Neolithic crop package, especially cereals, is equivalent to the Balkans and the Near East. The first farmers in the central and western Mediterranean have grown einkorn, emmer, free-treshing wheat, hulled and naked barley, a wide range of pulses, such as lentils, peas, beans, vetches, and grass peas, and flax. The set of cultivated plants is highly diversified. On Cardial sites from southern France and the Iberian Peninsula, naked cereals predominate, while emmer and einkorn appear to be predominant to the east, in the Central Mediterranean (Antolín et al., 2012; Buxó, 2007; Gassin et al., 2010; Peña-Choccaro et al., 2013). However, the more or less rigorous division between hulled cereals in the Impressa culture and naked cereals in the Cardial culture needs to be confirmed by further studies. Indeed, in the northeast of the Iberian Peninsula, the proportions of naked and hulled cereals 
vary depending the site (Antolín et al., 2012). Hulled cereals have been identified in some other sites on the central coast of Catalonia. In other sites, such as La Draga, the naked wheats dominate. There are no taphonomic, geological, or pedological features to explain these differences, indicating that several agricultural traditions in the choice of main cereals may have coexisted as soon as the early Neolithic at the micro-regional scale (Antolín et al., 2011, 2012). The two types of cereals (naked or hulled) do not have the same requirements, in terms of dehusking, for example, and involve different technical systems. However, the comparison of proportion is based on many cereals identified at the genus level (Triticum or Hordeum), which prevents a clear view of the naked/hulled dominances in the region. Moreover, this example illustrates quite well the limits of the sole morphological identification of the taxa to address early crop diversity. Indeed, genotype differences can be recorded within a field of wheat which looks visibly homogeneous, as it is currently highlighted in the western Mediterranean (Oliveira et al., 2012).

Regarding pulses, chickpea is absent from the Impressa/Cardial road, which indicates that it was not diffused by the very first farmers (Colledge et al., 2005). The reasons for this neglect are still poorly understood. It may or may not have been a conscious choice. Indeed, explanations of an exclusively environmental nature are difficult to substantiate, since all other taxa domesticated in the Near East are identified in the Mediterranean stream. Furthermore, we note the addition of common vetch (Vicia sativa) and broad bean (Vicia faba) as minor components of the crop package in the Mediterranean (Antolín et al., 2012; Rottoli et al. 2007, 2009). The findings of a large amount of broad bean in early Pre-Pottery Neolithic B (PPNB) occupation levels of Tell el-Kerkh (northwest Syria) and in a middle PPNB storage structure at Yiftah'el (Israel) could also point toward an early cultivation of this pulse in the area where the Neolithic crop package originated (Kislev, 1989). There is a real difficulty in differentiating wild and domesticated forms because of the overlapping of seed size, especially as these pulses could also be considered as a contaminant in cultivated fields (Zohary et al., 2012). Furthermore, charred archaeological pulses are very fragile, which does note facilitate their identification (Tanno et al., 2006). Thus, the origin and diffusion of pulses remains a largely unknown part of early agriculture, across the Mediterranean basin as well as the Near East.

An additionnal species, opium poppy (Papaver somniferum), completes the Mediterranean crop package and has not, to date, been identified,further east in the Balkan Peninsula and the Near East (see "LOOKING FOR THE ORIGIN OF OPIUM POPPY IN WESTERN EUROPE"). At La Marmotta, seeds preserved in carbonized and uncarbonized form, charred capsules, and stigmatic discs were discovered (Rottoli et al., 2007). In Spain, poppy has been identified in sites such as La Draga, Los Murceliagos, and La Lampara (Antolín et al., 2012; Stika, 2005).

\section{Diversity of first cultivated plants in Temperate Europe}

\section{Chrono-cultural background of the agriculture dispersal in Temperate Europe}

The Neolithic economy spread from south-central Europe, approximately following the Danube watershed, into northwestern continental Europe during the $6^{\text {th }}$ millennium BC. The first farmers of south-central Europe appear within the Starčevo/Körös/Criş complex (6100-5500 BC), which extend from Transdanubia to the Great Hungarian Plain and Transylvania. Around 5600 BC, the Linearbandkeramik ( $L B K$ ) culture emerged in southwestern Slovakia and western Hungary, to the north of Lake Balaton (Gronenborg, 1999). In this area, the relation between $L B K$ culture and the Starčevo/Körös/Criş complex are still subject to debate (Stadler et al., 2010). 
Around $5500 \mathrm{BC}$, the $L B K$ culture began its rapid first phase of expansion westward, reached the Rhine by $5300 \mathrm{BC}$ and, over a second phase, extended to the Paris Basin, and ended around 4900 BC (Bogucki, 2003). To the east, $L B K$ groups settled during the late $6^{\text {th }}$ millennium BC in Western Ukraine (Bogucki, 2000). $L B K$ material production shows some variation depending on location and chronology of the site. However, the cultural identity of the pioneer farmers is strong enough to follow the road of early agriculture diffusion through Temperate Europe from Southwest Ukraine to the Paris Basin. This culture is characterised by a broad distribution of similar pottery types and decoration as well as long houses with a rectangular layout. The decoration of pots-incised linear forms in bands or ribbons - provided the name for this archaeological culture (Linearbandkeramik, Linear Ceramic or Rubané). Houses and villages are clearly sedentary. The negatives of wood posts, called post holes, make it possible to trace the ground plan of the Danubian houses, which could measure between 10 and 45 meters (Coudart, 1998). The first farmers settled mainly on loessic patches, which are assumed to have a high natural fertility (Catt, 2004), and uninhabited zones separate clusters of villages from each other. $L B K$ emergence is believed by some to be linked to an increase of wetter and colder climatic conditions, and its collapse to warmer and drier conditions (Dubouloz, 2008).

\section{Crops diversity in Temperate Europe}

The Neolithic crop package in Central and Northwest continental Europe is quite well known, thanks to many archaeobotanical studies carried out in $L B K$ sites (e.g., Bakels, 1978; Knörzer, 1997; Kreuz, 2007; Kreuz et al., 2005; Salavert, 2011).

In the Starčevo/Körös/Crişsphere, at the origin of farming in Central Europe, the diversity of crops may be underestimated. Indeed, the plant economy of the Starčevo/Körös/Criş is mainly known through imprints in daub and ceramics. However, few sites from this period provide charred macroremains, which allow for an overview of the plants cultivated by the first farmers in South-Central Europe (Bogaard et al., 2011; Colledge et al., 2007b; Gyulai, 2010; Reed, 2015). To date, the list of crops is rather smaller. Both hulled wheats (einkorn and emmer) and, sometimes, barley as well as lens and peas are identifed. The arrival of naked wheat seems to have been delayed to the end of the $6^{\text {th }}$ millennium $\mathrm{BC}$, which corresponds to Late Neolithic (Reed, 2015).

In $L B K$ sites, the range of crops is also relatively narrow (Bakels, 2009; Colledge et al., 2005; Kreuz et al., 2005; Kreuz, 2007; Salavert, 2011). The general pattern shows that einkorn dominated central European sites for the duration of the LBK culture (Kreuz, 2007). Einkorn has a good resistance to lodging that could explain the choice of this cereal, despite its lower yield compared to emmer (Kreuz, 2007). However, west of the Rhine, in the southern Limbourg, Hesbaye, and Hainaut regions, emmer clearly dominates, whether it is the grains or chaff being taken into account (Salavert, 2011). Thus, a climatic hypothesis cannot be the only motivation beind humans' choices in their farming strategies. Concerning barley, hulled and naked forms are scarce, which gives an unknown status to this taxon. Barley, as for naked wheat, whose findings are anecdotal, may have been considered a weed in LBK fields and not a true crop plant (Kreuz, 2007). However, even if the barley form (hulled or naked) is not always specified in archaeobotanical counting tables because of bad conservation of the charred caryopses, naked barley seems more frequent in the western part of the LBK cultural extension, more precisely in the Hainaut and Parisian Basin, and could thus be part of the crop package in these peripheral regions of the primary Neolithic economy dispersal (Bakels, 2009; Salavert, 2011). Indeed, naked barley has been recognized at Wange and Overhespen in the north of Hesbaye (Bakels, 1992) and in four LBK sites in the Aisne valley in France (Bakels, 1999). 
The group of pulses is composed of lentils and peas. In the group of fibre/oleaginous plants, in addition to flax, opium poppy (Papaver somniferum) appears only in sites dated from 5300 BC and related to the second phase of LBK extension (Bakels, 1996; Kreuz, 2007; Salavert, 2011).

There is, thus, a clear decrease of crop diversity in Temperate Europe. This reduction corresponds to a moment of rupture in the diffusion of the Neolithic economy. The dynamic slows down, or stops, for several centuries on the level of the Hungarian plain. This pause allowed human societies, as well as the animals and plants they transported, to adapt to different climatic conditions (more humidity, longer winter) than those encountered previously. However, the cultural argument - that is to say, the choice made by the first farmers of Temperate Europe - cannot be ignored, as hulled wheats can also be successful in temperate environments (Colledge et al., 2005). This break could have enabled the groups to acquire agricultural know-how before being able to spread them into western and eastern Temperate Europe (Bogucki, 2000).

\section{Early farming systems in Mediterranean and Temperate Europe}

The definition of Neolithic farming systems, more precisely the seasonality of crops or the maintenance techniques of soil fertility, is at the center of archaeobotanical research, which relying on weeds and stable isotopes analyses.

In Central Europe, the specific diversity of weeds is also restricted. The most common species are Bromus secalinus, Chenopodium album, Fallopia convolvulus, and Lapsana communis. These are the main components of the plant association Bromo-Lapsanetum-Praehistoricum defined by Knörzer (1971), based on weed assemblages. However, this association is no longer observed in cultivated fields in Central Europe. According to several authors, it would show the presence of fields, permanent or not, cultivated every year with the same methods throughout the LBK territory, which would cause a well-defined combination of weeds (Bakels, 1978, 2009; Knörzer, 1971). It is difficult to interpret extinct associations to reconstruct past agricultural practices such as the size of fields, their sustainability, and the seasonality of crops. For a long time, the practice of slash-and-burn agriculture was suggested to explain the rapid expansion of early farmers in the forest environment of Central Europe. The principle is as follows: A forested area is cultivated over a short period (1 to 5 years) after being cleared and burned. Organic burned material provides nutrients that improve agricultural yield. After this short period, crops are moved to another area that has undergone the same treatment (Bogaard, 2002), allowing the initial site time to recover. However, the presence of long-lived Neolithic $L B K$ sites such as Langweiler 8 and Vaihingen and der Enz (Germany), as well as the spatial proximity of villages, does not offer an economic area wide enough to allow the operation of the system in each village across many generations.

Furthermore, the comparison of weed censuses from current experimental fields, in addition to a large number of archaeological weeds that have been precisely identified and come from deposits resulting from the processing of harvests of emmer and einkorn, exclude the possibility of shifting cultivation in the Early Neolithic in Temperate Europe (Bogaard, 2002). Indeed, with a shifting cultivation system, perennial weeds dominate. But, in archaeological assemblages, perennial weeds account for only $2 \%$ of the samples taken into account, and annual weeds dominate largely.

Thanks to weed autoecology, Bogaard (2004) has suggested that Early Neolithic farmers would have practiced intensive and permanent agriculture on a limited surface, usually near 
settlements. The sustainability of the fields was permitted thanks to a strong supply of animal manure and weeding. The main socio-technological implications are agricultural production at the domestic scale, strong integration between livestock and agriculture, and probably a very significant investement of labour and time (Jones, 2005; Saqalli et al., 2014). For example, manuring and weeding would be 6 to 7 times more labor intensive than shifting cultivation (Pétrequin et al., 2015). In the Balkans, the contribution of manure, as evidenced by nitogen isotope values $\left(\delta^{15} \mathrm{~N}\right)$, was integrated into agricultural systems from the very beginning of the spread of Neolithic economics (Bogaard et al., 2013; Fraser et al., 2013). Furthermore, at Vaihingen an der Enz, the integration of archeobotanical analyses, especially weed autoecology (such as soil $\mathrm{pH}$ requirements), and ceramic typology on a site almost completely excavated has led to claims of a sort of clanic/group organisation, with the distribution of cultivated areas according to group membership and a transfer of plots from generation to generation (Bogaard et al., 2011).

The Early Neolithic farming system in the Western Mediterranean has not been described in details mainly because of badly preserved archaeological weed assemblages at current sites. Statistical approaches, with precise identification based on substantial datasets, cannot yet be applied (Antolín et al., 2012). Furthermore, it is far too early to formulate a general trend applicable to the whole Mediterranean region. At los Castilleros, weed assemblages indicate permanent fields (Rovira, 2007). It seems that "most common taxa are annual plants typical of disturbed areas that could grow as arable weeds in irrigated or dry fields" (Antolín et al., 2012:99). The most common taxa are Chenopodium album and Galium aparine. The very few forest taxa in the assemblages could indicate that early farmers in Spain did not use the shifting cultivation (Antolín et al., 2014). The ecological requirements of annual plants and the flowering length indicate relatively intensive perturbations as well as long-term and intensively managed sowing of plots in autumn and possibly spring (Antolín et al., 2015; Pérez-Jordà et al., 2013).

\section{Looking for the origin of opium poppy in Western Europe}

\section{Identification of wild and cultivated poppy}

Opium poppy is a significant addition in the Neolithic crop package in the Meditterranean and Temperate Europe. Opium poppy could be one of the unique plants domesticated in the European territory during the Neolithic. The origin and diffusion of the plant in Western Europe are yet to be understood, especially the question of its wild progenitor.

The family Papaveraceae occurs in Temperate and Subtropical climates. Today, its main distribution is around the Mediterranean region and the Middle East (Baser et al., 2014). Papaver somniferum subsp. setigerum is often considered to be the wild ancestor of Papaver somniferum subsp. Somniferum, which is the cultivated form (Hammer, 1981; Zohary et al., 2012). However, recent botanical results based on their geographical distribution and the morphological characteristics of poppy identify three subspecies of poppy cultivated at present: $P$. somniferum subsp. setigerum, $P$. somniferum subsp. Songaricum, and $P$. somniferum subsp. somniferum. The putative wild ancestor can therefore also be considered as a cultivated form by botanists (Baser et al., 2014).

The Western and Central Mediterranean is the region of origin for wild poppy that is most often mentioned in archaeobotanical literature (Bakels, 1996; Knörzer, 1971; Schultze-Motel, 1979). However, wild populations of poppy have developed in other geographical areas, including Central Asia, the Caucasus, North Africa, and the Eastern Mediterranean (Salavert, 2010). 
Given the range of opium poppy, based on the occurrence of its wild ancestor and the evidence of current phytogeography, its origin is difficult to identify. The wild and cultivated forms of Papaver somniferum are interfertile, and wild populations that are supposed to be "authentic" may be naturalised populations or escaped from cultivated fields (De Candolle, 1995; Ladizinsky, 1998). This is why some authors believe that there are currently no known true wild populations of opium poppy in the world (Merlin, 1984; Chouvy, 2001). The wild ancestor and the natural distribution zone of wild poppy are therefore imprecise and may not be confined to the Western Mediterranean.

The morphological criteria to distinguish wild from cultivated seeds in archaeological records are not established. The poppy seed is small (less than $1 \mathrm{~mm}$ in diameter) and spherical. It has multiple facets, and is pentagonal and hexagonal edged with a slight bulge (Fig. 5). Capsules and stigmatic discs of opium poppy have also been identified at archaeological sites.

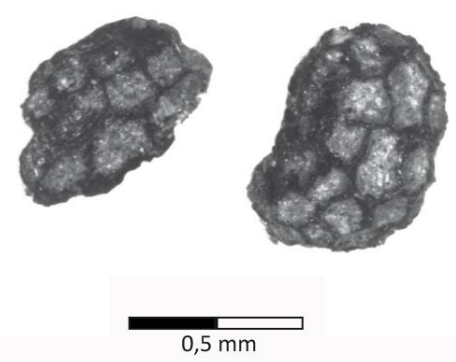

Figure 5: seeds of Papaver somniferum (opium poppy) from a Linearbandkeramik site in Belgium.

Although cultivated seeds are generally larger than wild seeds, there are no valid criteria for differentiating them (Hammer, 1981). The variability of cultivated poppy seeds is very broad and also covers the wild form. It is therefore impossible to distinguish between the seeds, as well as the capsule, of wild and cultivated poppy, especially from the Neolithic period. Furthermore, the number of seeds identified at archaeological sites is generally low. Particular taphonomical conditions must be present to preserve the seeds, and the remains most often originate from a single sample. This rarity can be attributed to the small size of the seeds, which requires a suitable sieving method $(0.25 \mu \mathrm{m}$ mesh). In the same way, the oil content of the seed does not predispose it to preservation. Finally, processes of poppy transformation may not necessitate contact with fire, which weakens the chances that the seeds will be charred and thus preserved at archaeological sites.

\section{Earliest neolithic poppy on archaeological sites}

The largest number of Neolithic archaeological sites that have delivered poppies are located in the Impressa/Cardial and $L B K$ complexes in Western Europe. In the current state of research, about thirty sites dated between 5200 and 5000 BC have delivered seeds of Papaver somniferum in the $L B K$. Sites are located in the area delimited by the province of Hesse (Germany) in the east and Hainaut (Belgium) in the west (Salavert, 2010). The seeds are absent from the earliest $L B K$ sites (5500-5300 BC), even in the case of sites located east of the Rhine, and appear only during the second phase of $L B K$ expansion, after $5300 \mathrm{BC}$. Outside this zone, several determinations are mentioned in France, Austria, and Poland, still at $L B K$ sites dating between 5200 and 5000 BC (Salavert, 2011). Thus, the opium poppy is well established in the $L B K$ context, in particular in the northwestern extension of the culture. In the Impressa/Cardial complex, a large quantity of carbonized and non-charred seeds, capsules, and stigmatic discs was found at the lakeside site of La Marmotta (Italy), dated by radiocarbon and dendrochronology between 5500 and 5400 BC (Kromer, 2009). At the site of La Draga (Spain), 
charred and watterlogged seeds were identified in one Neolithic structure. The archaeological level is dated between 5400 and $5100 \mathrm{BC}$, with a majority of dates between 5250 and $5150 \mathrm{BC}$ (Antolin et al., 2011). The opium poppy is mentioned in at least three other Cardial sites dated between 5200 and 4900 BC (Antolín et al., 2012; Salavert, 2011). The importance of the plant in the Neolithic Mediterranean has probably been underestimated because of the small size of the seeds and the mode of conservation (charred), which is not suitable for oleaginous seeds. The Eastern Mediterranean has also delivered poppy. A waterlogged seed was found at the Atlit-Yam Pre-Pottery Neolithic C (PPNC) site in Israel (Kislev et al., 2004). The series of radiometric datings obtained at the site ranges from about 7400 and $5900 \mathrm{BC}$. This is the single identification of Papaver somniferum in the Near Eastern Neolithic. The antiquity of the PPNC opium poppy seed can be questioned, on one hand, by its isolated nature in a region heavily investigated by archaeobotanists, and on the other hand, by the fact that only one (watterlogged) seed was discovered on this submerged site very favorable to the preservation of organic material. No opium poppy has been mentioned in Neolithic sites in Southeast Europe.

The Spanish and Italian arcaheological identifications, in a region supposedly at the origin of the (also supposed) ancestor of the plant, are weakly anterior to $L B K$ Europe. The limitations of the comparisons of dating are real, in particular the inaccuracy of radiocarbon datings, but above all the fact that it is not the poppy seeds that are directly dated but other materials (bones, charcoal) sometimes localized in other structures or archaeological layers that date the whole site or the occupation phase.

\section{Scenario of domestication and diffusion}

Absolute datings from the sites of the Early Neolithic period in Western Europe do not clearly indicate where the opium poppy was cultivated for the first time. One possibility is that the poppy accompanied the dispersal of Neolithic pioneer communities with other cultivated plants originating in the Near East, such as wheats, pulses, and flax. This hypothesis is uncertain because this plant has not been discovered, to date, in the earliest $L B K$ sites, the Starčevo/Körös/Criş or Balkano-Anatolian complex.

If we assume that the origin of the plant is the Western Mediterranean, poppy could have integrated the $L B K$ area under its wild or cultivated form. The contacts between the Neolithic populations of Southern and Northern Europe have also long been observed in archaeological artefacts. They are, for example, established between the Cardial-Epicardial farmers and the $L B K$ populations through ceramic decorations (e.g., Meier-Arendt, 1966; Guilaine et al., 1997) and ornaments (Bonnardin, 2009). In addition, wild plants, such as Bromus sterilis/tectorum and perhaps Setaria viridis/verticillata, identified occasionally in $L B K$ sites, originate from the Mediterranean regions (Oberdorfer, 1990). Thus, it is not suprising that seeds of Mediterranean origin are identified in $L B K$ archaeobotanical assemblages.

There have been no discoveries of incised capsules or other elements that would make it possible to understand the use of this plant by early farmers. Poppy can be grown for its oil, or the seeds may have been added to food preparations and consumed. The psychotropic properties may not have been unknown to the Neolithic societies. Furthermore, in Vaihingen an der Enz (Germany), it seems that only the houses located in the southeast of the site have adopted this plant. No different taphonomic conditions from the rest of the village could explain this spatial distribution. This could indicate a different social status of certain people as favored contacts with the Southern Cardial (Bogaard et al., 2011) or particular knowledge about poppy cultivation. 


\section{Spread of agriculture to northern and western Europe}

The presence of cultivated plants is a marker of the spread of the agrarian economy, especially when the seeds are dated directly to the radiocarbon, and are accompanied by weeds. On this basis, there is no convincing evidence of Mesolithic agriculture to date in the north and northwestern margins of Europe which correspond to southern Scandinavia, northern Germany and Poland, as well as Britain and Ireland (Behre, 2007, Sørensen and Karg, 2014, Tresset, 2015). The diffusion of cultivated plants is attested there from $4000 \mathrm{BC}$, which marks the beginning of the initial Neolithic, a little less than a millennium after the decline of the LBK culture in central and western temperate Europe (see "TEMPERATE DISPERSAL"). During this millennium, different archaeological cultures developed there, such as Blicquy / VilleneuveSaint-Germain, Rössen, Epi-Rössen, Michelsberg or Chasséen. Theirs social, cultural and economic structures are significantly different from those of the LBK pioneer farmers who travelled along the Danube from 5500 BC. Concerning cultivated plants, naked cereals have been developed, in particular tetraploid wheat (Triticum durum / turgidum), probably under the influence of neolithic populations from the western Mediterranean (Bakels, 2009).

The modalities for the introduction of cultivars at the beginning of the 4th millennium in the northern and western Europe are still discussed. The particular points are the progressive adoption of agriculture by indigenous mesolithic groups, the sudden arrival of cultivars thanks to small groups of experimented farmers from central Europe, as well as the importance of cereals compared to gathering/fishing/hunting products, in the early Neolithic diet (RowleyConwy, 2004, Jones et al., 2007, Thomas, 2008, Kreuz et al., 2014, Sørensen Karg, 2014, Jones and Sibbesson, 2016). Several factors are proposed to explain the relaunch of the crop diffusion to new geographical areas at the beginning of the $4^{\text {th }}$ millennium BC: demographic pressures, a warmer and drier climate around $4000 \mathrm{BC}$ which would extend the spring growing season for cereals, or the search for good flint sources (Bonsall et al., 2002, Jones et al., 2012, Sørensen and Karg, 2014).

According to radiocarbon dates, only three centuries have been needed to adopt the Neolithic economy, suggesting the arrival of small groups of experienced farmers in southern Scandinavia and northern Germany (Sørensen and Karg, 2014). Similarly, for southern Scandinavia, mitochondrial DNA studies show a close relationship between Neolithic individuals belonging to the northern Funnelbeaker culture (TRB or TBK), developing in northern Germany to the territory Sweden, with those of Central Europe (Malmström et al., 2015). In Britain and Ireland, different pollen records show that the disturbances of initial Neolithic people activities were sudden and rapid on deciduous forest (Woodbridge et al., 2014). However, seeds of cultivated cereals are still often identified in small amounts around 4000 BC (Jones and Rowley-Conwy, 2007). The agrarian economy seems fully established from 3750 BC in Ireland (Whitehouse et al., 2014, McClatchie et al., 2016) and from 3600 BC in northern Germany (Kirleis et al., 2011). However, taphonomic factors may explain the weak dataset related to early Neolithic settlements in these areas (Jones and Rowley-Conwy, 2007).

Archaeobotanical syntheses from southern Scandinavia (northern Germany, Denmark, southern and western Sweden) show that the main cultivated plants identified in the Funnelbeaker context, corresponding to local early and middle Neolithic, are emmer and einkorn as well as naked barley and bread wheat (Robinson, 2003, Larsson and Broström, 2011, Kirleis and Fischer, 2012). For northern Germany, poppy and pulses are not identified at the very beginning of the period (Kirleis and Fischer, 2012). Recently, discoveries of naked tetraploid wheat in southern Scandinavia support the possible cultural interaction between the Funnelbeaker and 
contemporaneous neolithic groups in Central Europe, such as the Michelsberg culture where this cereal is widely cultivated (Kirleis and Fischer, 2014, Kreuz et al., 2014). In the same way, the Michelsberg crop package is characterized by weak evidence of pulses (lentils and pea) and oleaginous/fiber plants (Kreuz et al., 2014). In Ireland, the early Neolithic is characterized by a mixed blend of cereals composed mainly of emmer, a few naked wheat (T. astivum / durum / turgidum) and naked barley. Einkorn is rare. Flax is present from the beginning of Neolithic while pulses are absent (McClatchie et al., 2014; 2016).

This is a very rapid view of the spread of Neolithic economy based on cereal cultivation in the northern margins of Europe. The northern and northwestern parts of Europe are therefore characterized by the importance of hulled wheat but also free-treshing wheat and naked barley, which corresponds to the main cereals cultivated by the Neolithic groups of Central Europe at the beginning of the $4^{\text {th }}$ millenium BC. Pulses are rare (Colledge et al., 2005). The characterization of farming systems is still in progress. In England, preliminary studies indicate a high rate of annual plants compared to perennial weeds characteristic of fields cultivated by a slash-and-burn system (Bogaard et al., 2007). As in Ireland, the intensive system of fixed and perennial fields in the landscape is favored (McClatchies et al., 2014).

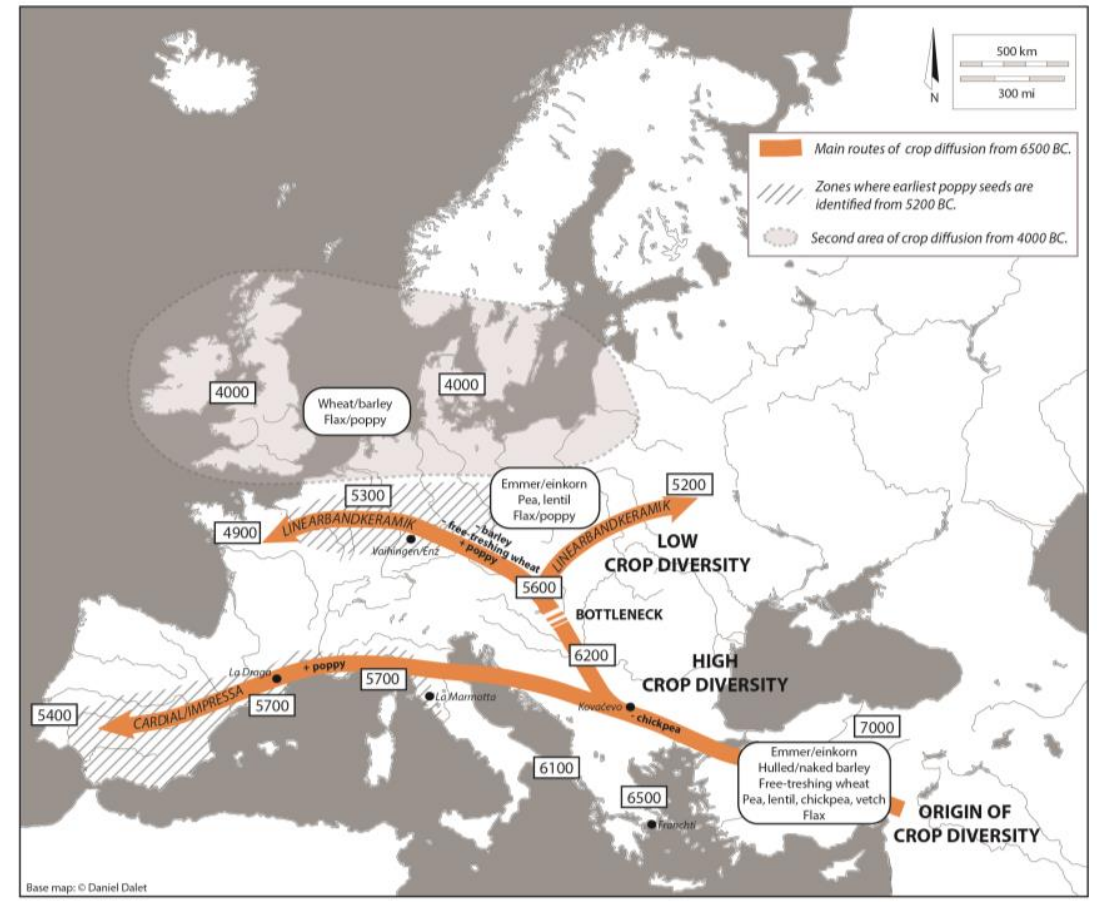

Figure 6: synthetic presentation of the maritim diffusion in Mediterranean (Impressa/Cardial) and continental diffusion in Temperate Europe (Linearbandkeramik) between 6500 and $4900 \mathrm{BC}$.

\section{Conclusions}

To sum up, the dispersal route of agriculture into Mediterranean and Temperate Europe is rather well known thanks to archaeology. The diffusion of the neolitic economy was rapid, covering about 1500 years, from the first point at $6500 \mathrm{BC}$ in Greece to the beginning of the $4^{\text {th }}$ millennium BC in Ireland (Fig. 6). The maritime road of agriculture dispersal, along the Mediterranean coasts, presents a minimal loss of diversity compared to agricultural origins in the Near East. Only the chickpea did not spread with the very first farming communities in the Balkans. Naked cereals are included in the crop package, but it seems that hulled wheats were prefered at the very beginning of the Neolithic diffusion (Balkans and Impressa). The habitat types (caves, rock shelters, open-air sites) are diversified, as are the crops that the first 
Mediterranean farmers cultivated from 6500 to 5500 BC. Farming practices need further investigation. Thanks to palaeocological studies, it seems that the first farming groups in the Western Mediterranean may have had a heterogeneous impact, in terms of timing and spatial extent, on the oak forests, which we assume earlier Mesolithic groups only sparsely modified (Revelles, in press; Thiébault, 1988).

In Temperate Europe, the habitat types are more homogeneous and the Neolithic crop package presents a low diversity. Cutlivated fields are probably long-lasting and may have been managed at the domestic scale under several family generations. This transfer goes hand in hand with the high investment required for agricultural work and the maintenance of the sustainability of the field (thanks to manure). It also implies a strong territorial settling of the groups of the early Neolithic in the Danubian sphere in the second half of the 6th millennium BC. Studies on daily firewood gathered near the $L B K$ sites of the first farmers in Belgium show the rapid increase in heliophilic taxa of hedges (Maloideae, for example). This dynamic may indicate the rapid opening of forest areas for the establishment of fields and their maintenance near habitats, as well as a local anthropic pressure on the landscape (Salavert et al., 2014a, 2014b). Less then one millennium after the end of the LBK culture, the agriculture knows a second wave of dispersal to northern and western Europe. As during the LBK, the high percentages of Maloideae and Corylus indicate that impact of Funnel beaker farmers on forest may have occurred on a small scale (Jansen et al., 2014).

The two routes, maritime and continental, thus show different dynamics in diffusion processes, cultures, and farming practices. Opium poppy is the main addition in western Europe, and its use concerns both regions. Many points must be highlighted in order to go further in the research on poppy domestication and uses. First, its wild progenitor is still not recognized with absolute certainty. Second, the status (wild or cultivated) of early Neolithic poppy is not understood, thanks to its seed morphology. Finally, the radiocarbon dating is indirect and not accurate enough to trace the diffusion process with precision. However, thanks to archaeological data, we do know that poppy was probably not integrated into the Neolithic crop package from the Near East or the Balkans. It seems to have been introduced in the Central and Western Mediterranean basin, from about $5400 \mathrm{BC}$ at the earliest, but most of the discoveries are from around $5200 \mathrm{BC}$, both in Mediterranean and Temperate Europe. The proximity of radiocarbon dating indicates that the diffusion from south to north might have been very rapid. The cultivation or the gathering of opium poppy does not seem to be shared by all farmers within an $L B K$ village. Thus, the plant seems to have had a different status than traditional crops, such as hulled wheat and pulses, in the Neolithic economy.

Cultivated plants are now known to be the basis of human alimentation in the Early Neolithic, although gathering also continued to be practiced, especially for foods such as hazelnuts, wild apples, and wild grapes. However, this part of the Neolithic diet, along with the status of wild trees in the farming system of the Early Neolithic, is not well understood. There are many aspects of the dispersal, notably crop diversity, and components of the farming system that need further investigations. The aDNA and stable isotope research currently in development will surely enhance our knowledge in this subject, without neglecting archaeobotanical works, which are still at the base of our knowledge of the very first farming communities in Europe. 


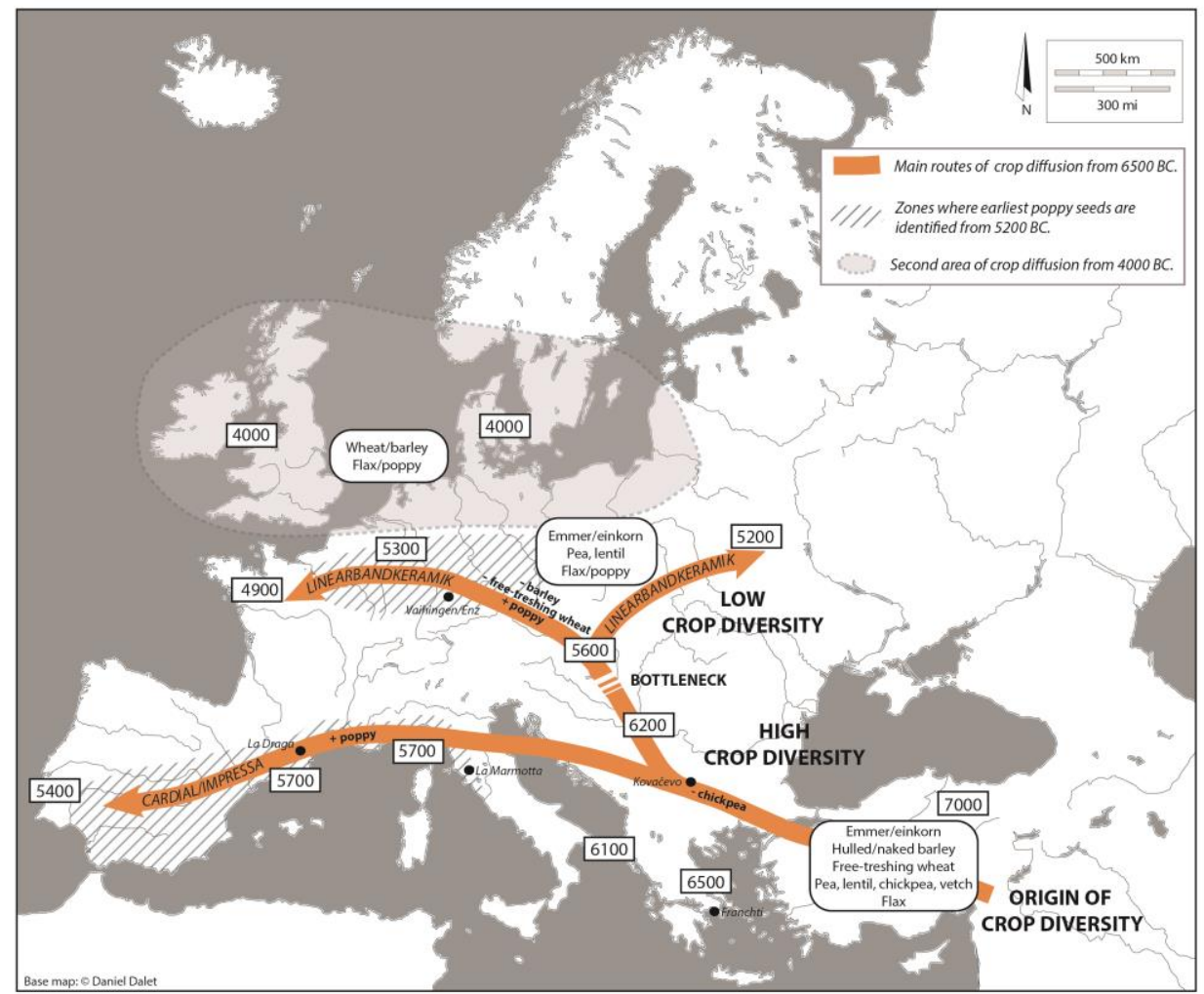

\section{References}

Antolín, F. (2011). L'explotació de les plantes: contribució a la història de l'agricultura i de l'alimentació vegetal del neolític a catalunya. In Bosch, A., Chinchilla, J., Tarrús, J. (Coord.) El poblat lacustre del neolític antic de La Draga: Excavacions de 2000-2005, Monografies del CASC 9 (pp.147-174). Girona: CASC-Museu d'Arqueologia de Catalunya.

Antolín, F., and Buxó, R. (2012). "Chasing the traces of diffusion of agriculture during the early neolithic in the western mediterranean coast. Rubricatum." Revista del Museu de Gavà 5: 95102.

Antolín, F., Buxó, R., Jacomet, S., Navarrete, V., and Saña, M. (2014). "An integrated perspective on farming in the early Neolithic lakeshore site of La Draga (Banyoles, Spain)." Environmental Archaeology 19: 241-255.

Antolín, F., Jacomet, S., and Buxó, R. (2015). "The hard knock life. Archaeobotanical data on farming practices during the Neolithic (5400-2300 cal BC) in the NE of the Iberian Peninsula." Journal of Archaeological Science 61: 36-44.

Ammerman, A.J., and Cavalli-sforza, L.L. (1971). "Measuring the rate of spread of early farming in Europe." Man New Series 6 (4): 674-688.

Bakels, C.C. (1978). "Four Linearbandkeramik settlements and their environment : a palaeoecological study of Sittard, Stein, Elsloo and Hienheim." Analecta Praehistorica Leidensia XI. Leiden: Modderman Stichting / Faculty of Archaeology - Leiden University. 
Bakels, C.C. (1992). "The botanical shadow of two early Neolithic settlements in Belgium : carbonized seeds and disturbances in a pollen record." Review of Palaeobotany and Palynology $73,1-19$.

Bakels, C.C. (1996). " Fruits and seeds from the Linearbandkeramik settlement at Meindling, Germany, with special reference to Papaver somniferum." Analecta Praehistorica Leidensia 25: 55-68.

Bakels C.C. (1999). "Archaeobotanical investigations in the Aisne valley, northern France, from the Neolithic up to the early Middle Ages." Vegetation History and Archaeobotany 8, 7177.

Bakels C.C. (2009). The Western European Loess Belt. (Dordrecth: Springer Science).

Baser, K. H. C., and Arslan, N. (2014). Oppium poppy. In Yaniv, Z., and Dudai, N. (Eds.) Medicinal and Aromatic Plants of the Middle-East (pp. 305-332). (Dordrecht: Springer Netherlands). doi:10.1007/978-94-017-9276-9_17

Berger, J.-F., and Guilaine, J. (2009). "The 8200calBP abrupt environmental change and the Neolithic transition: A Mediterranean perspective." Quaternary International 200, 31-49. doi: 10.1016/j.quaint.2008.05.013

Bocquet-Appel, J.-P. (2011). "The Agricultural Demographic Transition During and After the Agriculture Inventions. " Current Anthropology 52: S497-S510. doi: 10.1086/659243

Bonneuil, C., Demeulenaere, E., Thomas, F., Joly, P.-B., Allaire, G., and Goldringer, I. (2006). "Innover autrement ? La recherche face à l'avènement d'un nouveau régime de production et de régulation des savoirs en génétique végétale". Dossiers de l'environnement de l'INRA: 2951 .

Bogaard, A. (2002). "Questionning the relevance of shifting cultivation to Neolithic farming inthe loess belt of Europe: evidence from the Hambach Forest experiment." Vegetation History and Archaeobotany 11: 155-168.

Bogaard, A. (2004). Neolithic farming in central Europe (London: Routledge).

Bogaard, A., Hodgson, J. G., Wilson, P. J., and Band, S. R. (1998). "An index of weed size for assessing the soil productivity of ancient crop fields." Vegetation History and Archaeobotany 7: $17-22$.

Bogaard, A., and Jones, G. (2007). "Neolithic farming in Britain and central Europe: contrast or continuity?" Proceedings of the British Academy 144: 1-20.

Bogaard, A. and, Walker, A. (2011). Plant use and management at Măgura-Buduiasca (Teleor 003), southern Romania: Preliminary report on the archaeobotanical analysis. Brussels: Report prepared for the European Union: 1-23. 
Behre, K.E., and Jacomet, S. (1991). "The ecological interpretation of archaeobotanical data." In Van Zeist W., Wasylikowa, K., and Behre, K.E. (Eds.), Progress in Old World palaeoethnobotany (pp.81-108), Rotterdam: Balkema.

Bogaard, A. (2002). "Questioning the relevance of shifting cultivation to neolithic farming in the loess belt of Europe: evidence from the Hambach Forest experiment." Vegetation History and Archaeobotany 11: 155-168.

Bogaard, A. (2004). Neolithic farming in Central Europe. (London: Routledge).

Bogaard, A., Jones, G., Charles, M., and Hodgson, J. G. (2001). "On the Archaeobotanical Inference of Crop Sowing Time using the FIBS Method." Journal of Archaeological Science 28:1171-1183. doi: 10.1006/jasc.2000.0621

Bogaard, A., Krause, R. and Strien, H.-C. (2011). "Towards a social geography of cultivation and plant use in an early farming community: Vaihingen an der Enz, south-west Germany." Antiquity 85: 395-416.

Bogaard, A., Fraser, R., Heaton, T.H., Wallace, M., Vaiglova, P., Charles, M., Jones, G., Evershed, R.P., Styring, A.K., and Andersen, N.H. (2013). "Crop manuring and intensive land management by Europe's first farmers." Proceedings of the National Academy of Sciences of the United States of America 110: 12589-12594. doi: 10.1073/pnas.1305918110//DCSupplemental

Bogucki, P. (2000). "How Agriculture Came to North-Central Europe." In Price, T.D. (Ed.) Europe's First Farmers (pp. 197-218), (Cambridge: Cambridge University Press).

Bogucki, P. (2003). Neolithic dispersals in riverine interior Central Europe. In Ammerman, A., and Biagi, P. (Eds.) The Widening Harvest. The Neolithic Transition in Europe: Looking Back, Looking Forward (pp. 249-272), (Boston: Archaeological Institute of America, Colloquia and Conference Papers 6).

Bonnardin, S. (2009). La Parure funéraire au Néolithique ancien dans les bassins parisien et rhénan : Rubané, Hinkelstein et Villeneuve-Saint-Germain. Mémoire de la société préhistorique française 49. Paris: Société Préhistorique Française.

Bouby, L. (2000). "Restituer les pratiques agraires par la carpologie archéologique." Études rurales 153-154: 177-194.

Brown, T.A., Cappellini, E., Kistler, L., Lister, D. L., Oliveira, H. R., Wales, N. and Schlumbaum, A. (2014). "Recent advances in ancient DNA research and their implications for archaeobotany." Vegetation History and Archaeobotany 24: 207-214. doi: 10.1007/s00334014-0489-4

Buxó, R., (2007). Crop evolution: new evidence from the Neolithic of west Mediterranean Europe. In Colledge S. and Conolly J. (Eds.), The Origin and Spread of Domestic Plants in SW Asia and Europe (pp. 155-171), (Left Coast Press: California).

Candolle (de), A. (1883). Origine des plantes cultivées. éd. 1. (Paris: Germer Baillière). 
Catt, J.A. (2001). "The agricultural importance of loess." Earth-Science Reviews 54: 213-229.

Chevalier, A., Marinova, E., and Peña-Chocarro, E., eds. (2014). Plants and People: Choices and Diversity through Time. (Oxford and Philadelphia: Oxford Books).

Childe, G. (1925). The dawn of European civilization. (London: K. Paul, Trench, Trubner and Co.; New York: A.A. Knopf).

Chouvy P.A. (2001). "Le pavot à opium et l'homme. Origines géographiques et premières diffusions d'un cultivar." Annales de Géographie 618: 182-194.

Clark, J. G. D. (1965). "Radiocarbon dating and the expansion of farming culture from the Near East over Europe." Proceedings of the Prehistoric Society 31: 58-73. doi: 10.1017/S0079497X00014717

Colledge, S., Conolly J., and Shennan S. (2004). "Archaeobotanical Evidence for the Spread of Farming in the Eastern Mediterranean." Current Anthropology 45S: 3-38. doi: 10.1086/422086

Colledge, S., Conolly J., and Shennan, S. (2005). "The Evolution of Neolithic Farming from SW Asian Origins to NW European Limits." European Journal of Archaeology 8: 137-156. doi: $10.1177 / 1461957105066937$

Colledge, S., and Conolly, J. eds. (2007a). The origins and spread of domestic plants in Southwest Asia and Europe. (Walnut Creek, CA: Left Coast Press).

Colledge, S., and Conolly., J. (2007b). The neolithisation of the Balkans: a review of the archaeobotanical evidence. In P. Biagi and M. Spataro. (eds.) A Short Walk through the Balkans: the first farmers of the Carpathian basin and its adjacent regions, (pp. 2538), Quaderno 12, Atti della Società per la Preistoria e Protostoria della Regione Friuli Venezia Giulia. Trieste.

Coudart, A. (1998). Architecture et société néolithique : l'unité et la variance de la maison danubienne. Paris: Ed. de la Maison des sciences de l'homme.

Coward, F., Shennan, S., Colledge, S., Conolly, J., and Collard, M. (2008). "The spread of Neolithic plant economies from the Near East to northwest Europe: a phylogenetic analysis." Journal of Archaeological Science 35: 42-56. doi: 10.1016/j.jas.2007.02.022

Cristiani, E., Radini, A., Edinborough, M., and Borić, D. (2016). "Dental calculus reveals Mesolithic foragers in the Balkans consumed domesticated plant foods." Proceedings of the National Academy of Sciences of the United States of America 113 (37): 10298-10303. doi :10.1073/pnas.1603477113

Dubouloz, J. (2008). Impacts of the Neolithic demographic transition on Linear Pottery Culture settlement. In Bocquet-Appel, J.-P., Bar-Yosef, O. (Eds) The Neolithic demographic transition and its consequences (pp 207-235), (Berlin: Springer).

Fiorentino, F., Ferrio, R. P., Bogaard, A., Araus, J. L., and Riehl, S. (2015). "Stable isotopes in archaeobotanical research." Vegetation History and Archaeobotany 24: 215-227. doi:10.1007/s00334-014-0492-9. 
Forenbaher, S., Kaiser, T., and Miracle, P.T. (2013). "Dating the East Adriatic Neolithic." European Journal of Archaeology 16: 589-609. doi: 10.1179/1461957113Y.0000000038

Fraser, R.A., Bogaard, A., Schäfer, M., Arbogast, R., and Heaton, T.H.R. (2013). Integrating botanical, faunal and human stable carbon and nitrogen isotope values to reconstruct land use and palaeodiet at LBK Vaihingen an der Enz, Baden-Württemberg, World archaeology 45 (3): 492-517.

Fugazzola Delpino, M. A., and Tinazzi, O. (2010). Dati di cronologia da un villaggio del Neolitico Antico. Le indagini dendrocronologiche condotte sui legni de La Marmotta (lago di Bracciano-Roma), in Miscellanea in ricordo di Francesco Nicosia, Studia Erudita, Fabrizio Serra Editore.

Gassin, B., Bicho, N.F., Bouby, L., Buxó, R., Carvalho, A., Clemente Comte, I., Marinval, P., Philibert, S., Gibaja, J.-F., Gonzàlez Urquijo, J.E., Ibàñez, J. J., Linton, J., isepịarinval,

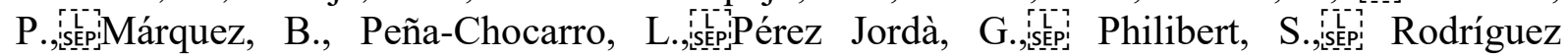
Rodríguez, A., and Zapata, L. (2010). Variabilité des techniques de récolte et traitement des céréales dans l'occident méditerranéen au Néolithique ancien et moyen: facteurs environnementaux, économiques et sociaux. In Beeching, A., Thirault E., and Vital, J. (eds.) Economie et société à la fin de la préhistoire. Actualité de la recherche. Actes des 7e Rencontres méridionales de Préhistoire récente, Bron, 3 et 4 novembre 2006. Documents d'archéologie en Rhône-Alpes et Auvergne ${ }^{\circ} 34$ (pp. 19-38). Lyon: ALPARA, Maison de l'Orient et de la Méditerranée.

Gebel, H.G. (2004). "There was no centre: The polycentric evolution of the Near Eastern Neolithic." Neo-lithics 1 (04): 28-32.

Gronenborn, D. (1999). "A variation on a basic theme: the transition to farming in southern central Europe." Journal of World Prehistory 13:123-210.

Guilaine, J. (2003). De la vague à la tombe. La conquête néolithique de la Méditerranée. (Paris: Éditions du Seuil).

Guilaine, J., and Manen, C. (1997). Contacts Sud-Nord au Néolithique ancien : témoignages de la grotte Gazel en Languedoc. In Jeunesse C. (dir.) Le Néolithique danubien et ses marges entre Rhin et Seine (pp. 301-311). Actes du 12e colloque interrégional sur le Néolithique, Strasbourg, octobre 1995. Association pour la promotion de la Recherche Archéologique en Alsace (Monographie d'Archéologie alsacienne 3).

Guilaine, J., and Manen, C. (2007). From Mesolithic to early Neolithic in the western Mediterranean. Whittle A. and Cummings V. (Eds.), Going over: The MesolithicNeolithicTtransition in the North-West Europe (pp. 21-51). Oxford University press, Proceedings of the British Academy 144.

Gyulai, F. (2010). Archaeobotanical research at the Körös culture site of Íbrany-Nagyerdő and its relationship to plant remains from contemporaneous sites in Hungary In Kozłowski, J. K., and Raczky, P., (Eds.) Neolithization of the Carpathian Basin: Northernmost Distribution of the Starčevo/Körös Culture (pp. 219-237). Kraków: Polska Akademia Umiejętności, Budapest: Institute of Archaeological Sciences of the Eötvös Loránd University. 
Hadjikoumis, A., Robinson, E., and Viner, S., Eds. (2011). The dynamics of neolithisation in Europe. Studies in honour of Andrew Sherratt. (Oxford: Oxbow Books).

Hammer, K. (1981). Problems of Papaver somniferum-classification and some remarks on recently collected European poppy land-races. Kulturpflanze XXIX: 287-296.

Heer, O. (1865). Die Pflanzen der Pfahlbauten. (Zürich: Druck von Zürcher und Furrer).

Jacobson, N. S. and Truax, P. (1991). "Clinical significance: A statistical approach to defining change in psychotherapy research." Journal of Consulting and Clinical Psychology 59: 12-19. doi:10.1037/0022-006X.59.1.12

Jones, G. (2005). "Garden cultivation of staple crops and its implications for settlement location and continuity." World Archaeology 37: 164-176. doi: 10.1080/00438240500094564

Jones, G., Charles, M., Colledge, S., and Halstead, P. (1995). Towards the archaeobotanical recognition of winter-cereal irrigation: an investigation of modern weed ecology in northern Spain. In H. Kroll and R. Pastemak (eds), Res Archaeobotanicae-9th Symposium IWGP (pp. 49-68). Kiel: Institut für Ur- und Frühgeschichte der Christain- Albrecht-Universität.

Jones, G., Bogaard, A., Charles, M., and Hodgson, J. G. (2000). ”Distinguishing the Effects of Agricultural Practices Relating to Fertility and Disturbance: a Functional Ecological Approach in Archaeobotany." Journal of Archaeological Science 27: 1073-1084. doi: 10.1006/jasc.1999.0543

Jouve, P. (1988). "Quelques réflexions sur la spécificité et l'identification des systèmes agraires." Les Cahiers de la Recherche Développement 20: 5-16.

Kislev, M.E. (1989). "Origins of the cultivation of Lathyrus sativus and L. cicera (Fabaceae)." Economic Botany 43: 262-270.

Kislev, M., Hartmann A., and Galili, E. (2004). ”Archaeobotanical and archaeoentomological evidence from a well at Atlit-Yam indicates colder, more humid climate on the Israeli coast during the PPNC period. ” Journal of Archaeological Science 31(9): 1301-1310.

Knörzer, K.H. (1997). Botanische untersuchung von 16 neolitischen siedlungsplätzen im bereich der Aldenhovener Platte, Kr. Düren und Aachen. In Lüning, J. (Ed) Studien zur neolitischen Besiedlung der Aldenhovener Platte und ihrer Umgebung ( $\mathrm{pp}$ 1-21). Bonn: Rheinland-Verlag GMBH.

Kreuz, A. (2007). Archaeobotanical perspectives on the beginning of agriculture north of the Alps. In Colledge S. et Conolly J. (dir.) The origins and spread of domestic plants in southwest Asia and Europe (pp. 259-294), (Left Coast Press, Walnut Creek/UCL Institute of Archaeology publications).

Kreuz, A., Marinova, E., Schäfer, E., and Wiethold, J. (2005). "A comparison of early Neolithic crop and weed assemblages from the Linearbandkeramik and the Bulgarian Neolithic cultures: differences and similarities." Vegetation History and Archaeobotany 14: 237-258. doi: 10.1007/s00334-005-0080-0 
Kunth, C. (1826). "Recherche sur les plantes trouvées dans les tombeaux égyptiens par M. Passalacqua." Annales des Sciences Naturelles 8: 418-423.

Ladizinsky, G. (1998). Plant evolution under domestication. (Dordrecht: Kluwer Academic publication).

Lespez, L., Tsirtsoni, Z., Darcque, P., Koukouli-Chryssanthaki, H., Malamidou, D., Treuil, R., Davidson, R., Kourtessi-Philippakis, G., and Oberlin, C. (2013). "The lowest levels at Dikili Tash, Northern Greece: a missing link in the Early Neolithic of Europe." Antiquity 87: 30-45, 2013.

Lichardus-Itten, M., Demoule, J-.P., Perničeva, L., and Grebska-Kulova, M. (2006). Kovacevo, an early Neolithic site in South-West Bulgaria and its importance for the European Neolithization. In Gatsov, I., and Schwarzberg, H. (Eds.) Aegean-Marmara-Black Sea: the present state of research on the early Neolithic (pp. 83-94). Schriften des Zentrums für Archäologie und Kulturgeschichte des Schwarzmeerraumes 5.

Lichardus-Itten, M. (2012). "Un bâtiment exceptionnel du Néolithique ancien à Kovačevo (Bulgarie)." Les nouvelles de l'archéologie 127: 25-30.

Lundström-Baudais, K. (1986). Etude paléoethnobotanique de la station III. In P. Pétrequin (ed.), Les sites littoraux néolithiques de Clairvaux-les-Lacs (Jura), I, Problématique générale, L'exemple de la station III (pp. 311-392), Paris: Ed. de la Maison des sciences de l'homme.

Manning, K., Colledge, S., Crema, E., Shennan, S., and Timpson, A. (2016). "The Cultural Evolution of Neolithic Europe. EUROEVOL Dataset 1: Sites, Phases and Radiocarbon Data." Journal of Open Archaeology Data. 5, p.e2. doi: http://doi.org/10.5334/joad.40

Marinova, E. (2007). Archaeobotanical data from the early Neolithic of Bulgaria. In S. Colledge and J. Conolly (Eds.), The Origin and Spread of Domestic Plants in SW Asia and Europe (pp. 93-109), (Left Coast Press: California).

Marinova, E., and Popova, T. (2008). "Cicer arietinum (chick pea) in the Neolithic and Chalcolithic of Bulgaria: implications for cultural contacts with the neighbouring regions?" Vegetation History and Archaeobotany 17: 73-80. doi: 10.1007/s00334-008-0159-5

Marinova, E., Tonkov, S., Bozilova, E. and Vajsov, I. (2012). "Holocene anthropogenic landscapes in the Balkans: the palaeobotanical evidence from southwestern Bulgaria." Vegetation History and Archaeobotany 21: 413-427. doi: 10.1007/s00334-011-0345-8

Marinova, E., and Valamoti, S. (2014). 3.2. Crop diversity and choices in the prehistory of SE Europe: the archaeobotanical evidence from Greece and Bulgaria. In Chevalier A., Marinova E., Peña-Chocarro L. (Eds.) Plants and People: Choices and Diversity Through Time (pp. 6474), (Oxford: Oxbow Books).

Mazoyer, M., and Roudart, L. (1997). Histoire des agricultures du monde. Du Néolithique à la crise contemporaine, (Paris: Seuil).

Mazurié de Keroualin, K. (2003). Genèse et diffusion de l'agriculture en Europe. agriculteurs, chasseurs, pasteurs. (Paris: Ed. Errance). 
Meier-Arendt, W. (1966). Die Bandkeramische Kultur im Untermaingebiet. Veroffentlichung des Amtes für Bodendenkmalpflege im Regierungsbezirk Darmstadt. (Bonn: Rudolf Habelt 3).

Merlin, M.D. (1984). On the trail of the ancient opium poppy. (Rutherford: Fairleigh Dickinson University Press).

Morales Hidalgo, J.I., Fontanals Torroja, M., Oms Arias, F.X., and Vergès Bosch, J.M. (2010). "La chronologie du Néolithique ancien cardial du nord-est de la péninsule Ibérique. Datations, problématique et méthodologie." L'Anthropologie 114: 427-444. doi: 10.1016/j.anthro.2010.07.004

Oberdorfer, E. (1990) Pflanzensoziologische Exkursionsflora für Deutschland und angrenzende Gebiete. (Stuttgart: Ulmer).

Oliveira, H.R., Campana, M.G., Jones, H., Hunt, H.V., Leigh, F., Redhouse, D.I., Lister, D.L., and Jones, M.-K. (2012). "Tetraploid Wheat Landraces in the Mediterranean Basin: Taxonomy, Evolution and Genetic Diversity." PLoS ONE 7(5): e37063. doi:10.1371/journal.pone.0037063

Orton, D., Gaastra, J., and Linden, M. V. (2016) "Between the Danube and the Deep Blue Sea: Zooarchaeological Meta-Analysis Reveals Variability in the Spread and Development of Neolithic Farming across the Western Balkans. "Open Quaternary 2.

Özdoğan, M. (2011). "Archaeological Evidence on the Westward Expansion of Farming Communities from Eastern Anatolia to the Aegean and the Balkans." Current Anthorpology 52: S415-S430. doi: 10.1086/658895

Peña-Chocarro, L., Pérez-Jordá, G., Morales Mateos, J., and Zapata, L. (2013). "Neolithic plant use in the western Mediterranean region: preliminary results from the AGRIWESTMED Project." Annali di Botanica 3: 135-141. doi: 10.4462/annbotrm-10306

Peña-Chocarro, L., Zapata, L., Iriarte, M.J., González Morales, M., and Straus, L.G. (2015). "The oldest agriculture in northern Atlantic Spain: new evidence from El Mirón Cave (Ramales de la Victoria, Cantabria)." Journal of Archaeological Science 32:579-587. doi: 10.1016/j.jas.2004.12.001

Pérez Jordà, G., and Peña-Chocarro, L. (2013). Agricultural production between the 6th and the 3rd millennium cal BC in the central part of the Valencia region (Spain). In Groot, M., Lentjes D. and Zeiler, J. (Eds) Barely Surviving or More than Enough? The environmental archaeology of subsistence, specialisation and surplus food production (pp.81-100), (Leiden: Sidestone Press).

Perlès, C. (1990). Les industries lithiques taillées de Franchthi (Argolide, Grèce). T. II : Les industries du Mésolithique et Néolithique initial (Excavations at Franchthi Cave, fasc. 5). (Bloominton-Indianapolis: Indiana University Press).

Perlès, C. (2001). The Neolithic in Greece. The farming communities in Europe. (Cambridge: Cambridge University Press). 
Perlès, C., Quiles, A., and Valladas, H. (2013). "Early seventh-millennium AMS dates from domestic seeds in the Initial Neolithic at Franchthi Cave (Argolid, Greece)." Antiquity 87: $1001-1015$.

Pétrequin, P., Pétrequin, A.-M., and Schaal, C. (2015). Chapitre 26. Introduction : rythmes d'occupation des villages et agriculture céréalière. In Petrequin P, and Petrequin A.M. (Eds.) Clairvaux et le "Néolithique Moyen Bourguignon » (pp. 1129-1150). Cahiers de la MSHE C.N. Besançon: Ledoux, Besançon, PUF et CRAVA.

Price, P.T., and Bar-Yosef, O. (2011). "The Origins of Agriculture: New Data, New Ideas." Current Anthropology 52 (S4): S163-S174.

Rasse, M. (2008). "La diffusion du Néolithique en Europe (7000-5000 av. J.-C.) et sa représentation cartographique.” M@ppemonde 90: 1-22.

Redden, R., Yadav, S.S., Maxted, N., Dulloo, M.E., Guarino, L., and Smith, P. (2015). Crop Wild Relatives and Climate Change. (John Wiley and Sons).

Reed, K. (2015). "From the field to the hearth: plant remains from Neolithic Croatia (ca. 60004000 cal bc)." Vegetation History and Archaeobotany 24: 601-619.

Revelles, J. (in press). "Archaeoecology of Neolithisation. Human-environment interactions in the NE Iberian Peninsula during the Early Neolithic." Journal of Archaeological Science: Reports. doi: 10.1016/j.jasrep.2016.02.004

Rottoli, M., and Pessina, A. (2007). Neolithic agriculture in Italy: an update of archaeobotanical data with particular emphasis on northern settlement. In S. Colledge and J. Conolly (Eds.), The Origin and Spread of Domestic Plants in SW Asia and Europe (pp. 141-153), (Left Coast Press: California).

Rottoli, M., and Castiglioni, E. (2009). "Prehistory of plant growing and collecting in northern Italy, based on seed remains from the early Neolithic to the Chalcolithic (c. 5600-2100 cal b.c.)." Vegetation History and Archaeobotany 18: 91-103. doi: 10.1007/s00334-007-0139-1

Rovira, N. (2007). Agricultura y gestión de los recursos vegetales en el Sureste de la península Ibérica durante la Prehistoria reciente. Ph-D dissertation, Universitad Pompeu Fabra.

Rowley-Conwy, P. (2011). "Westward Ho!" Current Anthropology 52: S431-S451. doi: $10.1086 / 658368$

Rowley-Conwy, P., Gourichon, L., Helmer, D., and Vigne, J.-D. (2013). Early domestic animals in Italy, Istria, the Tyrrenian Islands ad southern France. In Colledge, S., Conolly, J. Dobney, K., Manning, K. and Shennan, S. (Eds.) The Origins and Spread of Domestic Animals in Southwest Asia and Europe (pp.161-194), (Walnut Creek: Left Coast Press).

Salavert, A. (2010). "Le pavot (Papaver somniferum) à la fin du 6e millénaire av. J.-C.en Europe occidentale." Anthropobotanica 1: 1-14. 
Salavert, A. (2011). "Plant economy of the first farmers of central Belgium (Linearbandkeramik, 5200-5000 b.c.). "Vegetation History and Archaeobotany 20: 321-332. doi: 10.1007/s00334-011-0297-z

Salavert, A., Bosquet, D., and Damblon, F. (2014a). "Natural woodland composition and vegetation dynamic during the Linearbandkeramik in north-western Europe (central Belgium, 5200-5000 b.c.)." Journal of Archaeological Science 51:84-93. doi: 10.1016/j.jas.2012.10.017

Salavert, A. and, Dufraisse, A. (2014b). "Understanding the impact of socio-economic activities on archaeological charcoal assemblages in temperate areas: A comparative analysis of firewood management in two Neolithic societies in Western Europe (Belgium, France)." Journal of Anthropological Archaeology 35:153-163. doi: 10.1016/j.jaa.2014.05.002

Saqalli, M., Salavert, A., Bréhard, S., Bendrey, R., Vigne, J.-D., and Tresset, A. (2014). "Revisiting and modelling the woodland farming system of the early Neolithic Linear Pottery Culture (LBK), 5600-4900 b.c." Vegetation History and Archaeobotany 23(1): 37-50. doi: 10.1007/s00334-014-0436-4

Schlumbaum, A., Tensen, M., and Jaenicke-Després, V. (2008). "Ancient plant DNA in archaeobotany." Vegetation History and Archaeobotany 17: 233-244. doi: 10.1007/s00334007-0125-7

Schultze-Motel, J. (1979). "The prehistoric remains of the opium poppy (P. somniferum) and the theory of the species." Kulturplanze 27: 207-216.

Shennan, S.J. (2013). "Demographic Continuities and Discontinuities in Neolithic Europe: Evidence, Methods and Implications." Journal of Archaeological Method and Theory 20 (2): 300-311.

Stadler, P., and Kotova, N. (2010). Early Neolithic settlement from Brunn-Wolfholz in Lower Austria and the problem of the origin of (western) LBK. In Kozłowski, J.K., and Raczky, P. (Eds.) Neolithisation of the Carpathian Basin: northernmost distribution of the Starcevo culture (pp. 325-348), (Kraków: Polska Akademia Umiejętności).

Stika, H.-P. (2005). "Early Neolithic agriculture in Ambrona, Provincia Soria, central Spain." Vegetation History and Archaeobotany 14: 189-197. doi: 10.1007/s00334-005-0085-8

Tanno, K-I., and Willcox, G. (2006). "The origins of cultivation of Cicer arietinum L. and Vicia faba L.: early finds from Tell el-Kerkh, north-west Syria, late 10th millennium b.p." Vegetation History and Archaeobotany 15: 197-204. doi: 10.1007/s00334-005-0027-5.

Thiébault, S. (1988). L'homme et le milieu végétal au Tardi et Postglaciaire dans les préalpes sud-occidentales. Document d'Archéologie Française 15. (Paris: Editions de la Maison des Sciences de l'Homme).

Thomas, D. S., Knight, M., and Wiggs, G. F. (2005). "Remobilization of southern African desert dune systems by twenty-first century global warming." Nature 435(7046): 1218-1221. 
Unger, F., Lesquereux, L., and Hruschauer, F. (1851). Über die im Salzberge zu Hallstatt im Salzkammergute vorkommenden Pflanzentrümmer, Viena.

Valamoti, S., and Kotsakis, K. (2007). Transitions to agriculture in the Aegean: the archaeobotanical evidence. In S. Colledge and J. Conolly (Eds.), The Origin and Spread of Domestic Plants in SW Asia and Europe (pp. 75-92), (Left Coast Press: California).

Valamoti, S.M., Moniaki, A., and Karathanou, A. (2011). "An investigation of processing and consumption of pulses among prehistoric societies: archaeobotanical, experimental and ethnographic evidence from Greece." Vegetation History and Archaeobotany 20: 381-396. doi: $10.1007 / \mathrm{s} 00334-011-0302-6$

Vaquer, J., and Ruas, M.-P. (2009). La grotte de l'Abeurador, Félines-Minervois (Hérault): occupations humaines et environnement du Tardiglaciaire à l'Holocène. Mélanges offerts à Jean Guilaine (pp. 761-792), (Toulouse: Archives d'Ecologie Préhistorique).

Vavilov, N.I. (1951). "The origin, variation, immunity and breeding of cultivated plants." Chron. Bot. 13: 1-366.

Vigne, J.D. (2007). Exploitation des animaux et néolithisation en Méditerranée nordoccidentale. In Guilaine, J., Manen, C. and Vigne, J.-D. (Eds), Pont de Roque-Haute (Portiragnes, Hérault). Nouveaux aperçus sur la néolithisation de la France méditerranéenne (pp. 221-301), (Toulouse: Centre d'Anthropologie).

Vigne, J.-D., Briois, F., Zazzo, A., Willcox, G., Cucchi, T., Thiébault, S., Carrère, I., Franel, Y., Touquet, R., Martin, C., Moreau, C., Comby, C., and Guilaine, J. (2012). "First wave of cultivators spread to Cyprus at least 10,600 y ago." Proceedings of the National Academy of Sciences of the United States of America 109: 8445-8449.

Warner, T. T. (2004). Desert meteorology. (Cambridge, U.K.: Cambridge University Press).

Weninger, B., Alram-Stern, E., Bauer, E., Clare, L., Danzeglocke, U., Jöris, O., Kubatzki, C., Rollefson, G., Todorova H., and van Andel, T. (2006). "Climate forcing due to the $8200 \mathrm{cal}$ yr BP event observed at Early Neolithic sites in the eastern Mediterranean." Quaternary Research 66: 401-420. doi: 10.1016/j.yqres.2006.06.009.

Willcox, G. (2005). "The distribution, natural habitats and availability of wild cereals in relation to their domestication in the Near East: multiple events, multiple centres." Vegetation History and Archaeobotany 14: 534-541. doi: 10.1007/s00334-005-0075-x.

Willcox, G. (2007). The adoption of farming and the beginnings of the Neolithic in the Euphrates valley: cereal exploitation between the 12th and the 8th millennium BC cal. In S. Colledge and J. Conolly (Eds.), The Origin and Spread of Domestic Plants in SW Asia and Europe (pp. 21-36), (Left Coast Press: California).

Zapata, L., Peña-Chocarro, L., Pérez-Jordá, G., and Stika, H.-P. (2004). "Early Neolithic Agriculture in the Iberian Peninsula." Journal of World Prehistory 18: 283-325. doi: 10.1007/s10963-004-5621-4 
Zilhão, J. (2014). Early Food Production in Southwestern Europe. In Renfrew, C., Bahn, P. (Eds.) The Cambridge World Prehistory. Volume 3. West and Central Asia and Europe (p. 1818-1834), (Cambridge: University Press).

Zohary, D. (1996). The mode of domestication of the founder crops of Southwest Asian agriculture. In Harris D.R. (Ed.), The origins and spread of agriculture and pastoralism in Eurasia (pp. 142-158), (London: University College London Press).

Zohary, D., Hopf, M., and Weiss, E. (2012). Domestication of plants in the Old World, $4^{\text {th }}$ ed. (Oxford: Oxford University Press).

\section{Suggested Readings}

Bakels C.C. (2009). The Western European Loess Belt. (Dordrecth: Springer Science).

Bogaard, A. (2004). Neolithic farming in central Europe (London: Routledge).

Colledge S. and Conolly J. (Eds.), The Origin and Spread of Domestic Plants in SW Asia and Europe (pp. 155-171), (Left Coast Press: California).

Zohary, D., Hopf, M., and Weiss, E. (2012). Domestication of plants in the Old World, $4^{\text {th }}$ ed. (Oxford: Oxford University Press). 